\title{
The potential of hypoxia markers as target for breast molecular imaging - a systematic review and meta-analysis of human marker expression
}

Arthur Adams ${ }^{1 *}$, Aram SA van Brussel ${ }^{2 \dagger}$, Jeroen F Vermeulen², Willem PThM Mali ${ }^{1}$, Elsken van der Wall ${ }^{3}$, Paul J van Diest ${ }^{2}$ and Sjoerd G Elias ${ }^{1,4}$

\begin{abstract}
Background: Molecular imaging of breast cancer is a promising emerging technology, potentially able to improve clinical care. Valid imaging targets for molecular imaging tracer development are membrane-bound hypoxia-related proteins, expressed when tumor growth outpaces neo-angiogenesis. We performed a systematic literature review and meta-analysis of such hypoxia marker expression rates in human breast cancer to evaluate their potential as clinically relevant molecular imaging targets.
\end{abstract}

Methods: We searched MEDLINE and EMBASE for articles describing membrane-bound proteins that are related to hypoxia inducible factor 1 a (HIF-1a), the key regulator of the hypoxia response. We extracted expression rates of carbonic anhydrase-IX (CAIX), glucose transporter-1 (GLUT1), C-X-C chemokine receptor type-4 (CXCR4), or insulin-like growth factor-1 receptor (IGF1R) in human breast disease, evaluated by immunohistochemistry. We pooled study results using random-effects models and applied meta-regression to identify associations with clinicopathological variables.

Results: Of 1,705 identified articles, 117 matched our selection criteria, totaling 30,216 immunohistochemistry results. We found substantial between-study variability in expression rates. Invasive cancer showed pooled expression rates of 35\% for CAIX (95\% confidence interval (CI): 26-46\%), 51\% for GLUT1 (Cl: 40-61\%), 46\% for CXCR4 (Cl: 33-59\%), and 46\% for IGF1R (Cl: 35-70\%). Expression rates increased with tumor grade for GLUT1, CAIX, and CXCR4 (all $p<0.001$ ), but decreased for IGF1R ( $p<0.001$ ). GLUT1 showed the highest expression rate in grade III cancers with 58\% (45-69\%). CXCR4 showed the highest expression rate in small T1 tumors with 48\% (Cl: 28-69\%), but associations with size were only significant for CAIX ( $p<0.001$; positive association) and IGF1R ( $p=0.047$; negative association). Although based on few studies, CAIX, GLUT1, and CXCR4 showed profound lower expression rates in normal breast tissue and benign breast disease $(p<0.001)$, and high rates in carcinoma in situ. Invasive lobular carcinoma consistently showed lower expression rates $(p<0.001)$.

Conclusions: Our results support the potential of hypoxia-related markers as breast cancer molecular imaging targets. Although specificity is promising, combining targets would be necessary for optimal sensitivity. These data could help guide the choice of imaging targets for tracer development depending on the envisioned clinical application.

Keywords: Breast cancer, Carbonic anhydrase-IX, CAIX, Glucose transporter-1, GLUT1, C-X-C chemokine receptor type-4, CXCR4, Insulin-like growth factor-1 receptor, IGF1R, Expression prevalence, Systematic review, Meta-analysis, Molecular imaging, Immunohistochemistry, Carcinoma in situ, Benign breast disease, Normal breast tissue

\footnotetext{
* Correspondence: A.Adams@umcutrecht.nl

${ }^{\dagger}$ Equal contributors

'Department of Radiology, University Medical Center Utrecht, Utrecht,

The Netherlands

Full list of author information is available at the end of the article
}

\section{Biomed Central}

(c) 2013 Adams et al.; licensee BioMed Central Ltd. This is an open access article distributed under the terms of the Creative Commons Attribution License (http://creativecommons.org/licenses/by/2.0), which permits unrestricted use, distribution, and reproduction in any medium, provided the original work is properly cited. 


\section{Background}

In the past decades, conventional breast imaging modalities such as (digital) mammography, breast ultrasound, and more recently dynamic contrast enhanced magnetic resonance imaging (DCE-MRI), have improved detection, characterization, and management of breast cancer. Although these imaging modalities are valuable in clinical practice, novel imaging strategies such as molecular imaging promise additional advantages. With molecular imaging techniques, breast cancer could be detected even before anatomical changes occur that are required for visualization with currently used imaging modalities, making it valuable for early detection or screening. For diagnostic purposes, more informative characterization of breast cancer could result in less unnecessary biopsies. Furthermore, improved imaging of the extent of disease could lead to better preoperative planning and to peroperative guidance, increasing the primary surgery success rate. Molecular imaging could also be applied to demonstrate the presence of appropriate molecular targets in the primary tumor, lymph node and distant metastasis (in vivo receptor status determination), and could therefore be useful to tailor therapy to individual patients and to monitor therapy response [1-6]. Molecular imaging of tumor metabolism using ${ }^{18} \mathrm{~F}$-fluorodeoxyglucose $\left({ }^{18} \mathrm{~F}\right.$-FDG) Positron Emission Tomography is currently common for imaging and staging of advanced breast cancer. However, it is of limited value in evaluation of early breast cancer because of limited spatial resolution, non-visibility of tumors with low ${ }^{18}$ F-FDG avidity, and low specificity [7].

Imaging of tumor hypoxia could be a feasible alternative strategy for molecular imaging of breast cancer. Hypoxia is a frequent phenomenon in solid tumors that arises due to limited perfusion [8,9], and might therefore be more specific than ${ }^{18}$ F-FDG imaging. Direct imaging of tumor hypoxia using oxygen mimetics (e.g. with radiolabelled 2-nitroimidazole derivatives $\left({ }^{18} \mathrm{~F}\right.$-FMISO, ${ }^{18} \mathrm{~F}$ FAZA, ${ }^{18}$ F-EF5) and other molecules such as Cu-ATSM) has been investigated in several clinical studies [10]. However, the biodistribution properties of these molecules result in images with low contrast.

Molecular imaging using (monoclonal) antibodies or antibody fragments (e.g. single chain variable fragments (scFv), antibody-binding fragments (Fab), variable domains of the heavy chain of heavy chain-only antibodies (VHH) or affibodies) that have high affinity for markers that are expressed in breast cancer under hypoxic conditions could improve imaging contrast [11-13]. The molecules that are targeted with these antibodies or fragments should ideally be highly prevalent in (breast) cancer, and expression should preferably be already present at the initial stage of tumorigenesis. Expression of these molecules should be absent or low in non-affected tissue and benign breast disease for high specificity, although the relative importance of these properties depends on the envisioned clinical application. For screening purposes, specificity of the target of interest should be high and for application in a diagnostic setting, expression prevalence of the target in breast cancer should be sufficient. For intra-operative guidance, high expression prevalences are less important as pre-operative target selection is possible based on a diagnostic (core) biopsy. However, distribution of the target within the tumor should be homogenous when used for assessment of tumor margins. Furthermore, extracellular membrane bound molecules are most attractive, as these are more easily accessible for most antibodies or antibody fragments compared to intracellular molecules [14].

Hypoxic conditions result in focal expression of hypoxia inducible factor $1 \alpha$ (HIF-1 $\alpha)$, the key regulator of the hypoxia response $[8,15,16]$. The downstream targets of HIF-1 $\alpha$, carbonic anhydrase IX (CAIX), glucose transporter 1 (GLUT1) and C-X-C chemokine receptor type 4 (CXCR4) [17-20], and insulin-like growth factor 1 receptor (IGF1R) that maintains the hypoxia response via HIF-1 $\alpha$ stabilization [21-23], are expressed on the plasma membrane of breast cancer cells and are therefore potentially suitable candidates for molecular imaging of hypoxic tumors with antibodies or antibody fragments.

Despite the apparent potential of these hypoxia related proteins, expression patterns in human breast cancer, normal breast tissue and benign breast diseases, as well as expression in tumor margins and heterogeneity within tumors are not well established. To evaluate whether molecular imaging using these targets could be clinically relevant, we performed a systematic literature review and meta-analysis to quantify expression prevalences of these hypoxia markers in breast disease as assessed by immunohistochemistry (IHC), investigated relations with clinicopathological characteristics, and assessed the influence of specimen handling on these prevalences. These data could help guide the choice of relevant imaging targets for future tracer development towards clinical studies.

\section{Methods}

\section{Literature search}

We performed a systematic search in the databases of MEDLINE and EMBASE on August $21^{\text {st }}, 2012$. Search terms included synonyms for the targets of interest (CXCR4, GLUT1, CAIX, and IGF1R), combined with 'breast' and 'mamm*'. The full search syntax can be found in Table 1. We applied no restrictions on publication date. The search in the database of EMBASE was limited to articles that were not indexed with a MEDLINE ID, and conference abstracts were excluded. Duplicate articles were manually removed from the search results. 
Table 1 Search strategy used to identify publications of interest regarding prevalence of hypoxia proteins in benign and malignant breast tissue

\begin{tabular}{ll}
\hline Target & Synonyms used \\
\hline CAIX & CAIX OR CA-IX OR "CA IX" OR CA9 OR CA-9 OR "CA 9" OR "carbonic anhydrase IX" OR "carbonic anhydrase 9" \\
GLUT1 & GLUT1 OR GLUT-1 OR "glucose transporter 1" \\
CXCR4 & CXCR4 OR CXCR-4 OR CXC-R4 OR "CXC chemokine receptor-4" \\
IGF1R & "insulin like growth factor 1 receptor" OR "insulin like growth factor I receptor" OR IGF1R OR IGF-1R OR IGFR OR IGF-IR OR IGF1-R \\
\hline
\end{tabular}

Search terms were combined with 'breast' and 'mamm*'. For MEDLINE, '[tiab]' was added to each search term, and for EMBASE, 'ti;ab;' was added to each search term.

\section{Article selection}

Article eligibility was assessed by three reviewers (AA, $\mathrm{AvB}, \mathrm{JV}$ ) through independent screening of all titles and abstracts from the search result (triple read). We excluded articles based on predefined criteria, disagreements were resolved by discussion. An overview of the selection procedure is shown in Figure 1. Reasons for exclusion of articles based on title or abstract were: (1) non-original data (e.g. reviews, editorials, guidelines, and comments), (2) non-clinical articles (e.g. technical, animal, or in vitro studies), (3) case reports, (4) articles investigating other tissues than breast tissue, or (5) articles not written in the English language. The full texts of the remaining articles were screened for expression prevalence of the targets of interest. Studies were excluded if (1) only lymph node or distant metastases were investigated $(\mathrm{N}=10),(2)$ the target

Potentially relevant articles identified through MEDLINE $(\mathrm{N}=1629)$ and EMBASE $(\mathrm{N}=270)$ on August 21st, 2012

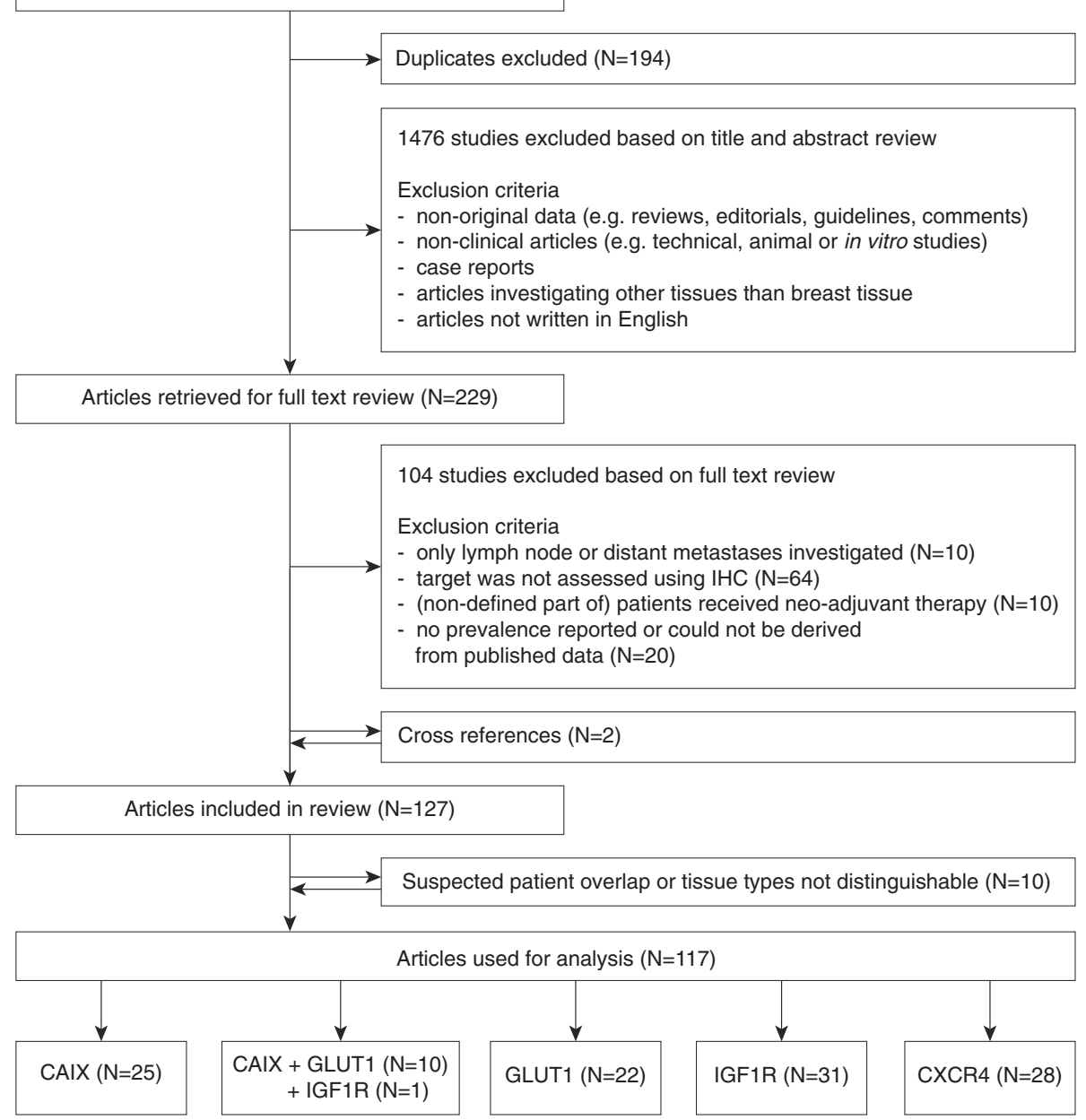

Figure 1 Flowchart for selection of articles describing expression prevalences of the hypoxia markers CAIX, GLUT1, CXCR4, and IGF1R in breast cancer, normal tissue, benign breast disease, and carcinoma in situ, assessed by immunohistochemistry. 


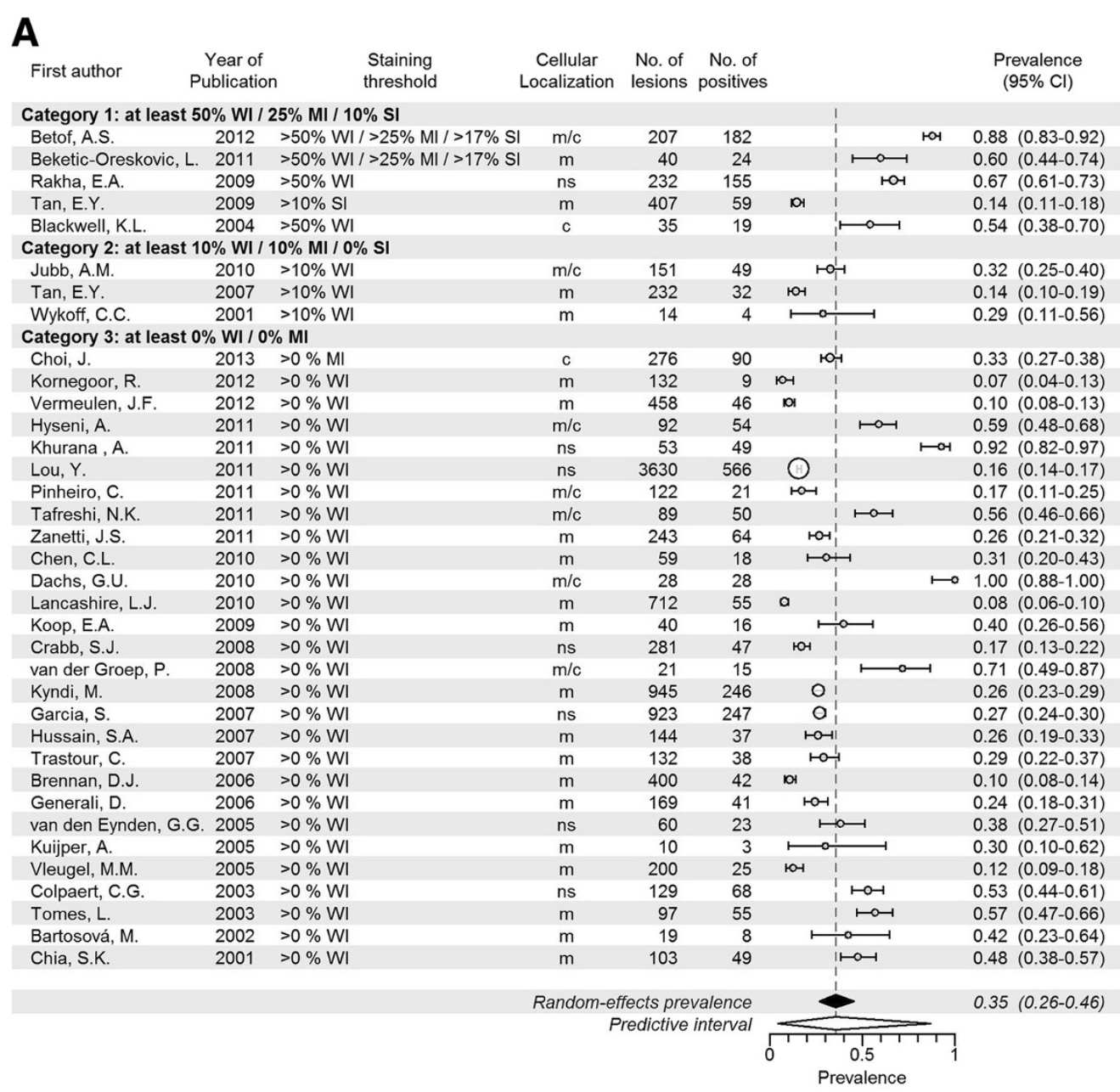

B

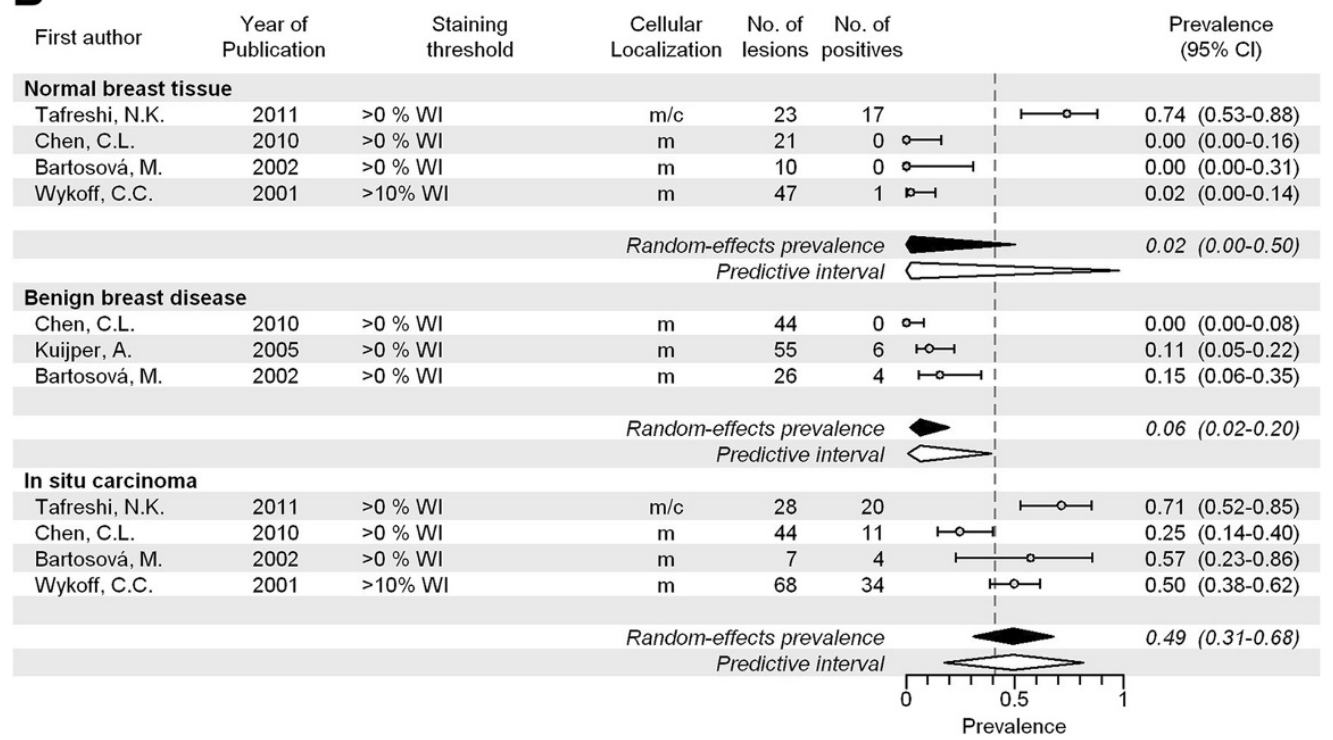

Figure $\mathbf{2}$ (See legend on next page.) 
(See figure on previous page.)

Figure 2 Expression prevalence of CAIX. A Systematic literature review of CAIX prevalence in breast cancer assessed by immunohistochemistry, according to reported staining threshold. Legend: Dashed gray reference line: overall random-effects prevalence estimate. Abbreviations: Staining threshold: weak intensity (WI), moderate intensity (MI), strong intensity (SI); Localization: cytoplasm (c), membrane (m); confidence interval (CI); not stated (NS). B Systematic literature review of CAIX prevalence in normal breast tissue, benign breast diseases and carcinoma in situ assessed by immunohistochemistry. Legend: Dashed line represents random effect summary prevalence estimate for invasive cancer within studies reporting also on normal, benign and/or precancerous breast tissue (4 studies). Abbreviations: Staining threshold: weak intensity (WI), moderate intensity (MI), strong intensity (SI); Localization: cytoplasm (c), membrane (m); confidence interval (CI); not stated (NS).

of interest was assessed with another method than IHC (e.g. quantitative Polymerase Chain Reaction or Western Blot, $\mathrm{N}=64$ ), (3) all or a non-definable part of patients received neo-adjuvant therapy (which could profoundly alter biomarker status, $\mathrm{N}=10$ ), or (4) the prevalence of the target of interest was not reported and could not be derived from the published data $(\mathrm{N}=20)$. All references of the remaining articles were reviewed to retrieve articles initially missed in the search syntax.

\section{Data extraction and statistical analysis}

We extracted relevant information of each study (e.g. study and population characteristics, patient and tumor characteristics, and IHC methodology). Then, for each study and per target of interest, we annotated the number of lesions stated as target-positive and the total number of lesions, either directly or through recalculation based on the information stated in the article. Lesions of interest were invasive breast cancers, carcinoma in situ, benign breast lesions, or normal breast tissue. For invasive cancers, we grouped studies describing similar cut-off levels for marker positivity. When a study described multiple cut-off levels, the level corresponding to the most used cut-off among other included studies was used, as established after collecting all data. If patient data was used in more than one article (i.e. when articles referred to the same study, or assessed a comparable number of patients from the same hospital in a similar inclusion period to evaluate the expression of the same hypoxia marker), then only the article with the largest number of patients was included in the review and meta-analysis. A subgroup was defined for studies investigating membranous staining patterns only. Also, in order to assess applicability of the targets for human molecular imaging studies, we identified articles using a stringent or high cut-off value and preferentially membranous staining localization, as these studies provide the best evidence for high expression levels of the target. Furthermore, subgroups were defined according to tumor size (based on the TNM staging system), histological grade, histological subtype, and specimen handling method (i.e. if full tissue sections or tissue microarrays (TMA) were investigated), when stated. To assess specificity of the investigated markers, studies were grouped according to tissue types other than invasive breast cancer (normal tissue, benign breast disease, carcinoma in situ).

Then, we pooled prevalence rates across studies using a random-effects model, allowing for between-study heterogeneity. We fitted a linear mixed model using the exact binomial approach with the restricted maximum likelihood method [24]. We tested for subgroup differences using meta-regression analysis with subgroup indicators as fixed effects and the individual studies as random effects in the models. Besides the pooled prevalence estimates, we report predictive intervals as suggested by Higgins et al. for the evaluation of between-study heterogeneity [25]. We evaluated presence of publication bias with funnel plots and statistically tested for funnel plot asymmetry using Egger's test [26].

Analyses were performed with $\mathrm{R}$ (version 2.15.1, R Foundation for Statistical Computing, Vienna, Austria) [27] with the package 'lme4' [28] and 'meta' [29]. All statistical tests were two-sided and a p-value of 0.05 or less was considered statistically significant. Prevalence estimates are reported with corresponding 95\% logit confidence intervals (CI).

\section{Results}

The search yielded 1,629 articles in MEDLINE and 270 articles in EMBASE. After removal of 194 duplicates, 1,705 unique articles were left for evaluation. Of these, we excluded 1,476 articles based on title and abstract, and 104 articles based on full text screening (Figure 1). Reference cross-checking of the selected articles yielded two additional studies that were initially missed, as synonyms for breast were not included in the title or abstract [30,31]. Of the 127 selected articles (CAIX [9,32-71], GLUT1 [30,31,33,34, 36,39,42,45,46,49,53,62,65,67,69,72-91], CXCR4 [92-121] IGF1R [36,122-156]), we excluded ten articles from the analysis due to (suspected) overlap of study populations $[38,43,61,62,94,109,123,139,143,153]$, and one article [67] because we could not distinguish between carcinoma in situ and invasive breast cancer. Ten articles [33,34,39, 42,45,46,49,53,65,69] described both GLUT1 and CAIX expression, and one study [36] described IGF1R, CAIX, and GLUT1 expression. In three of these studies, co-expression patterns of CAIX and GLUT1 were 
Table 2 Systematic review, meta-analysis and meta-regression results of hypoxia membrane protein expression in breast cancer, in situ carcinoma, benign breast disease, and normal breast tissue.

\begin{tabular}{|c|c|c|c|c|c|c|c|c|c|c|c|c|c|c|c|c|}
\hline & \multicolumn{4}{|c|}{ CAIX } & \multicolumn{4}{|c|}{ GLUT1 } & \multicolumn{4}{|c|}{ CXCR4 } & \multicolumn{4}{|c|}{ IGF1R } \\
\hline & $\mathrm{N}$ & Prev. & $(\mathrm{Cl})$ & p-value* & $\mathbf{N}$ & Prev. & $(\mathrm{Cl})$ & p-value* & $\mathrm{N}$ & Prev. & $(\mathrm{Cl})$ & p-value* & $\mathrm{N}$ & Prev. & $(\mathrm{Cl})$ & p-value* \\
\hline \multicolumn{17}{|l|}{ Invasive carcinoma } \\
\hline Overall & 36 & 0.35 & $(0.26-0.46)$ & Ref & 33 & 0.51 & $(0.40-0.61)$ & Ref & 28 & 0.46 & $(0.33-0.59)$ & Ref & 31 & 0.46 & $(0.35-0.70)$ & Ref \\
\hline Membranous localization only & 20 & 0.23 & $(0.17-0.31)$ & - & 19 & 0.44 & $(0.37-0.52)$ & - & 2 & 0.16 & $(0.08-0.31)$ & - & 15 & 0.38 & $(0.27-0.50)$ & - \\
\hline Best evidence studies & 6 & 0.38 & $(0.17-0.65)$ & - & 17 & 0.41 & $(0.35-0.48)$ & - & 7 & 0.43 & $(0.25-0.63)$ & - & 10 & 0.33 & $(0.22-0.46)$ & - \\
\hline Histological grade & 12 & & & & 10 & & & & 13 & & & & 5 & & & \\
\hline I & & 0.04 & $(0.02-0.08)$ & Ref & & 0.24 & $(0.18-0.31)$ & Ref & & 0.26 & $(0.13-0.44)$ & Ref & & 0.57 & $(0.51-0.63)$ & Ref \\
\hline$\|$ & & 0.16 & $(0.10-0.24)$ & $<0.001$ & & 0.33 & $(0.20-0.50)$ & 0.012 & & 0.32 & $(0.17-0.52)$ & 0.049 & & 0.51 & $(0.49-0.54)$ & 0.093 \\
\hline III & & 0.30 & $(0.22-0.39)$ & $<0.001$ & & 0.58 & $(0.45-0.69)$ & $<0.001$ & & 0.44 & $(0.26-0.63)$ & $<0.001$ & & 0.41 & $(0.39-0.43)$ & $<0.001$ \\
\hline Tumor size & 7 & & & & 6 & & & & 12 & & & & 4 & & & \\
\hline $\mathrm{T} 1$ & & 0.12 & $(0.11-0.14)$ & Ref & & 0.37 & $(0.31-0.42)$ & Ref & & 0.48 & $(0.28-0.69)$ & Ref & & 0.45 & $(0.39-0.51)$ & Ref \\
\hline $\mathrm{T} 2$ & & 0.15 & $(0.11-0.20)$ & $<0.001$ & & 0.36 & $(0.29-0.43)$ & 0.641 & & 0.52 & $(0.28-0.74)$ & 0.620 & & 0.47 & $(0.44-0.49)$ & 0.682 \\
\hline $\mathrm{T} 3$ & & 0.30 & $(0.17-0.47)$ & $<0.001$ & & 0.30 & $(0.14-0.53)$ & 0.180 & & 0.68 & $(0.53-0.80)$ & 0.122 & & 0.39 & $(0.32-0.47)$ & 0.047 \\
\hline Histological type & 13 & & & & 14 & & & & 10 & & & & 6 & & & \\
\hline Invasive ductal carcinoma & & 0.34 & $(0.20-0.52)$ & Ref & & 0.48 & $(0.32-0.64)$ & Ref & & 0.46 & $(0.22-0.72)$ & Ref & & 0.42 & $(0.28-0.58)$ & Ref \\
\hline Invasive lobular carcinoma & & 0.01 & $(0.00-0.05)$ & 0.001 & & 0.09 & $(0.01-0.40)$ & $<0.001$ & & 0.35 & $(0.00-0.98)$ & 0.001 & & 0.25 & $(0.08-0.55)$ & $<0.001$ \\
\hline Specimen handling & 36 & & & & 32 & & & & 28 & & & & 31 & & & \\
\hline Full sections & & 0.51 & $(0.37-0.64)$ & Ref & & 0.61 & $(0.49-0.72)$ & Ref & & 0.39 & $(0.28-0.51)$ & Ref & & 0.34 & $(0.26-0.42)$ & Ref \\
\hline Tissue microarray & & 0.24 & $(0.16-0.35)$ & 0.002 & & 0.30 & $(0.18-0.45)$ & 0.003 & & 0.61 & $(0.29-0.85)$ & 0.173 & & 0.57 & $(0.39-0.73)$ & 0.032 \\
\hline Other tissue types & 4 & & & & 5 & & & & 6 & & & & 4 & & & \\
\hline Normal breast tissue & & 0.02 & $(0.00-0.50)$ & $<0.001$ & & 0.03 & $(0.00-0.22)$ & $<0.001$ & & 0.03 & $(0.01-0.07)$ & $<0.001$ & & 0.74 & $(0.69-0.78)$ & 0.109 \\
\hline Benign breast diseases & & 0.06 & $(0.02-0.20)$ & $<0.001$ & & 0.04 & $(0.00-0.42)$ & $<0.001$ & & 0.04 & $(0.00-0.80)$ & $<0.001$ & & 0.73 & $(0.66-0.79)$ & 0.137 \\
\hline Carcinoma in situ & & 0.49 & $(0.31-0.68)$ & 0.025 & & 0.52 & $(0.42-0.62)$ & 0.680 & & 0.71 & $(0.23-0.95)$ & $<0.001$ & & 0.33 & $(0.18-0.53)$ & 0.869 \\
\hline
\end{tabular}

*p-values obtained using meta-regression (linear mixed model with subgroup indicators as fixed and the individual studies as random effects); ref: reference

category for the meta-regression result; N: Maximum number of studies evaluated for pooled estimate or meta regression; prev.: expression prevalence of the investigated target. 
A

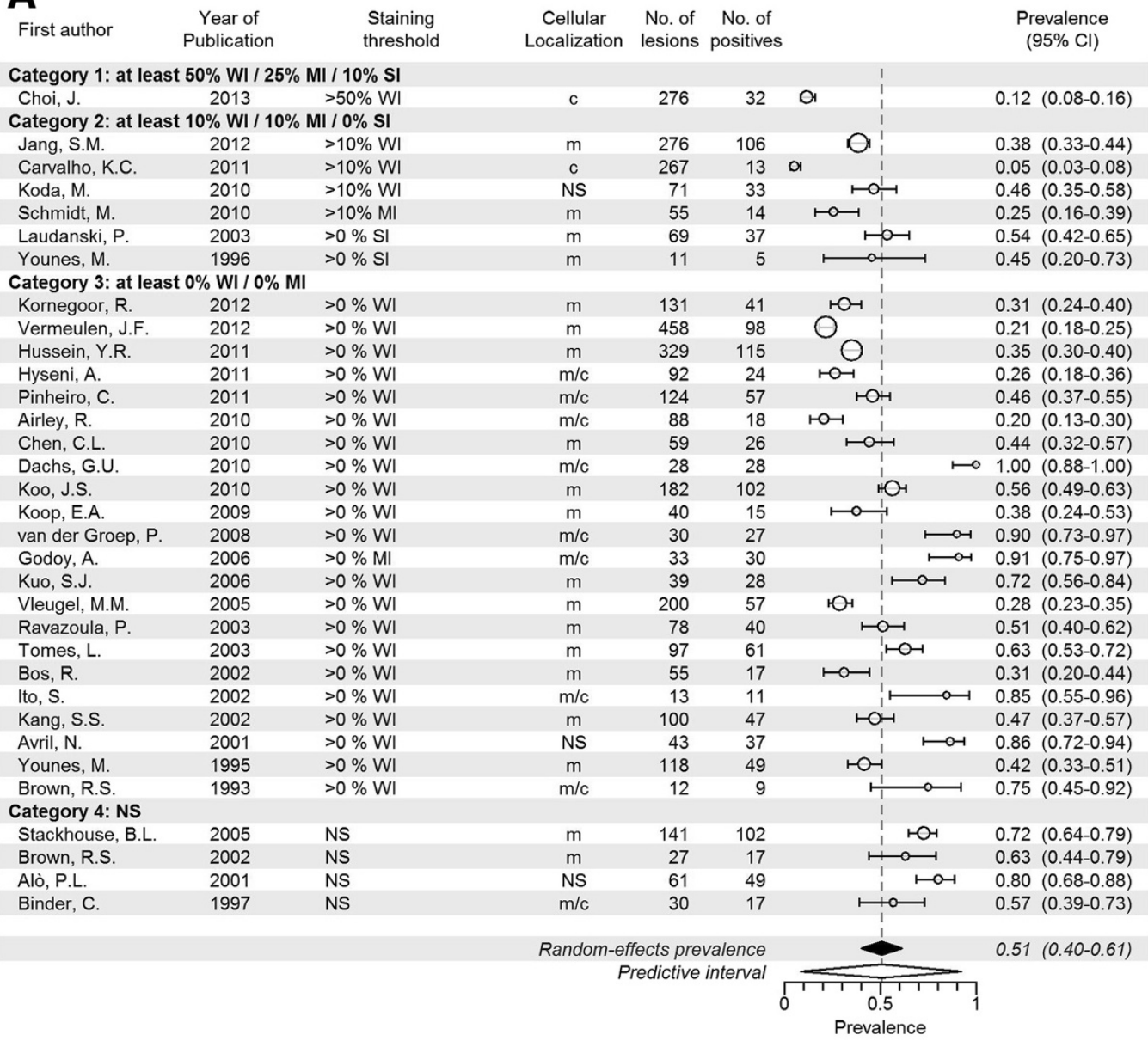

B

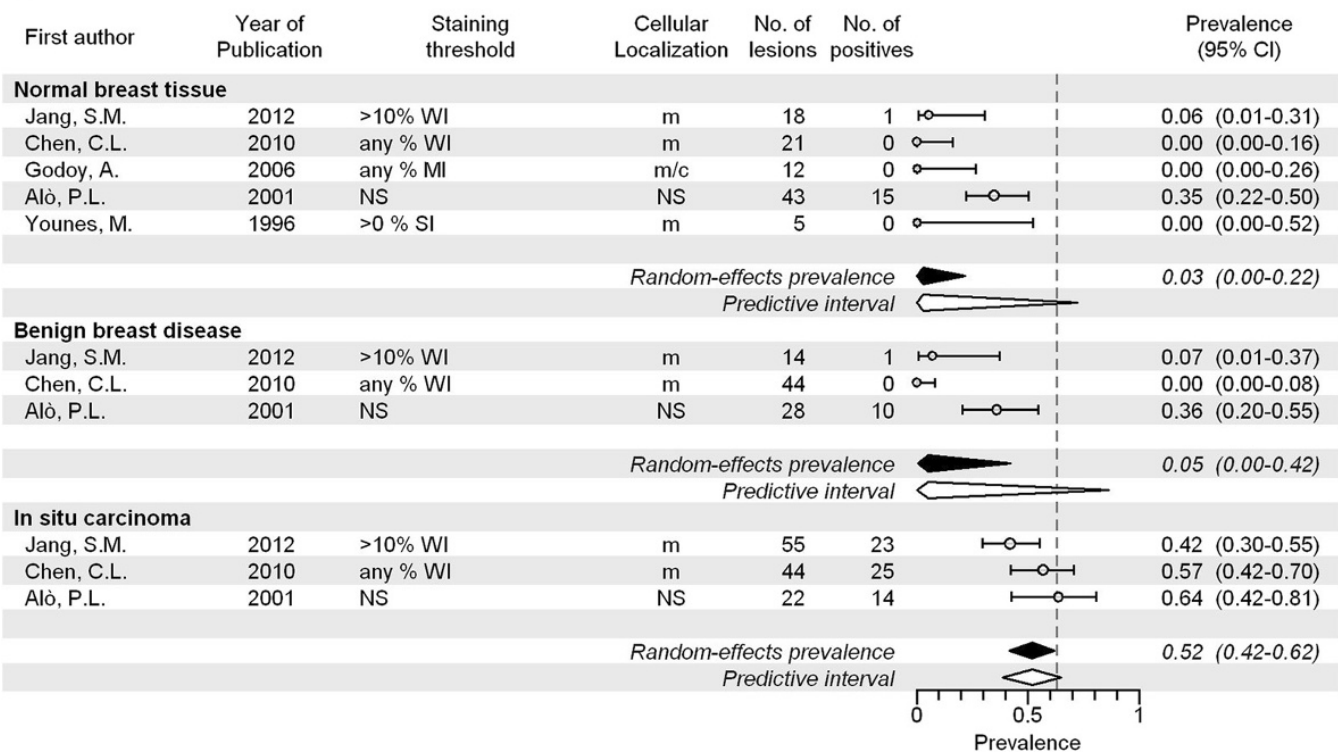

Figure 3 (See legend on next page.) 
(See figure on previous page.)

Figure 3 Expression prevalence of GLUT1. A Systematic literature review of GLUT1 prevalence in breast cancer assessed by immunohistochemistry, according to reported staining threshold. Legend: Dashed gray reference line: overall random-effects prevalence estimate. Abbreviations: Staining threshold: weak intensity (WI), moderate intensity (MI), strong intensity (SI); Localization: cytoplasm (c), membrane (m); confidence interval (CI); not stated (NS). B Systematic literature review of GLUT 1 prevalence in normal breast tissue, benign breast diseases and carcinoma in situ assessed by immunohistochemistry. Legend: Dashed line represents random effect summary prevalence estimate for invasive cancer within studies reporting also on normal, benign and/or precancerous breast tissue ( 5 studies). Abbreviations: Staining threshold: weak intensity (WI), moderate intensity (MI), strong intensity (SI); Localization: cytoplasm (c), membrane (m); confidence interval (Cl); not stated (NS).

investigated [42,45,69]. Study characteristics of all investigated studies are shown in Additional file 1: Table S1A, Additional file 2: Table S1B, Additional file 3: Table S1C, Additional file 4: Table S1D.

IHC methodology varied between the studies. For assessment of CAIX expression, three different antibodies were used, and in 11 studies (31\%) only the manufacturer was stated. In articles describing GLUT1 prevalence, six different antibodies were used and in 23 studies (70\%) only the manufacturer was stated. For CXCR4, eight antibodies were used and in seven studies (25\%) the antibody data was not reported, and for IGF1R, 11 different antibodies were used, and five studies (16\%) did not specify the clone used. In addition, 51 studies (44\%) investigated TMAs to evaluate the expression of the target of interest. Only 32 studies (63\%) using TMAs reported the number of cores, and 37 studies $(73 \%)$ reported the diameter of the cores. In 43 of the studies (37\%) no information was available on who assessed staining results, 18 studies (15\%) reported evaluation by a single observer and in 56 studies (48\%) by more than one observer. In 43 of the studies (37\%), it was explicitly stated that evaluation was performed by one or more pathologists.

\section{CAIX}

A total of 36 articles including 10,885 invasive cancers (range of 10 to 3,630 cancers per study) reported on CAIX expression, with prevalence estimates ranging from $7 \%$ to $92 \%$. The overall pooled prevalence of CAIX was $35 \%$ (CI 26-46\%; Figure 2A and Table 2). For studies investigating membranous staining patterns only, we found a pooled expression prevalence of $23 \%$ (CI 17-31\%, 20 studies; Additional file 5: Figure S1A) and the studies providing best evidence for evaluation of molecular imaging targets showed a pooled prevalence of $38 \%$ (CI 17-65\%, 6 studies; Additional file 6: Figure S1B). Expression prevalence of CAIX increased with histological grade $(16 \%$ in grade II $(\mathrm{p}<0.001)$ and $30 \%$ in grade III $(\mathrm{p}<0.001)$ versus $4 \%$ in grade I; Additional file 7 : Figure S1C), and tumor size $(15 \%$ in T2 $(\mathrm{p}<0.001)$ and $30 \%$ in T3 ( $\mathrm{p}<0.001$ ) versus $12 \%$ in T1; Additional file 8 : Figure S1D). Prevalence of CAIX was also higher in invasive ductal carcinoma (IDC) compared to invasive lobular carcinoma (ILC) (34\% versus 1\%, p = 0.001; Additional file 9: Figure S1E). CAIX expression was more often positive in studies investigating full sections compared to TMA ( $51 \%$ versus 24\%, $\mathrm{p}=0.002$; Additional file 10: Figure S1F). In normal breast tissue, the pooled prevalence was $2 \%$ (CI 0-50\%, p $<0.001 ; 4$ studies). Pooled prevalence in benign lesions was 6\% (CI 2-20\%, p < 0.001; 3 studies), and in carcinoma in situ 49\% (CI 31-68\%, p = 0.025; 4 studies) (Figure 2B). Overall, between study-heterogeneity of studies investigating CAIX expression was large, but this decreased when confining analyses to membranousonly and best evidence studies (these study groups largely overlapped). Between-study variation was also lower within subgroups of tumor grade and tumor size.

\section{GLUT1}

A total of 33 articles including 3,633 invasive cancers reported on GLUT1 expression, with a range of 11 to 458 cancers per study. The overall pooled prevalence of GLUT1 expression was 51\% (CI 40-61\%; Figure 3A and Table 2), but the reported prevalence varied substantially between studies (range 5\% to 100\%). For studies investigating membranous staining patterns only, the pooled prevalence was 44\% (CI 37-52\%, 19 studies; Additional file 11: Figure S2A) and when the studies providing best evidence for evaluation of molecular imaging targets were selected, this was 41\% (CI 35-48\%; 17 studies; Additional file 12: Figure S2B). GLUT1 prevalence was higher for grade III $(58 \%, \mathrm{p}<0.001)$ and grade II tumors $(33 \%, \mathrm{p}=$ $0.012)$ compared to grade I tumors (24\%; Additional file 13 : Figure S2C), but there was no relation with tumor size (Additional file 14: Figure S2D). Furthermore, as for CAIX, expression prevalence in ILC was lower compared to IDC (9\% versus 48\%, p < 0.001; Additional file 15: Figure S2E). Studies investigating TMAs reported lower prevalence of GLUT1 expression compared to studies using full sections (30\% versus $61 \%, \mathrm{p}=0.003$, Additional file 16: Figure S2F). In normal breast tissue, the pooled expression prevalence was 3\% (CI 0-22\%, p < 0.001; 5 studies). Pooled prevalence in benign lesions was $5 \%$ (CI $0-42 \%, \mathrm{p}<0.001 ; 3$ studies), and in carcinoma in situ 52\% (CI 42-62\%, $\mathrm{p}=0.680 ; 3$ studies) (Figure 3B). For GLUT1, the overall between-study variation was large as well, but substantially smaller for studies investigating membranous staining only and the best evidence studies (these study groups again largely overlapped). Furthermore, the 


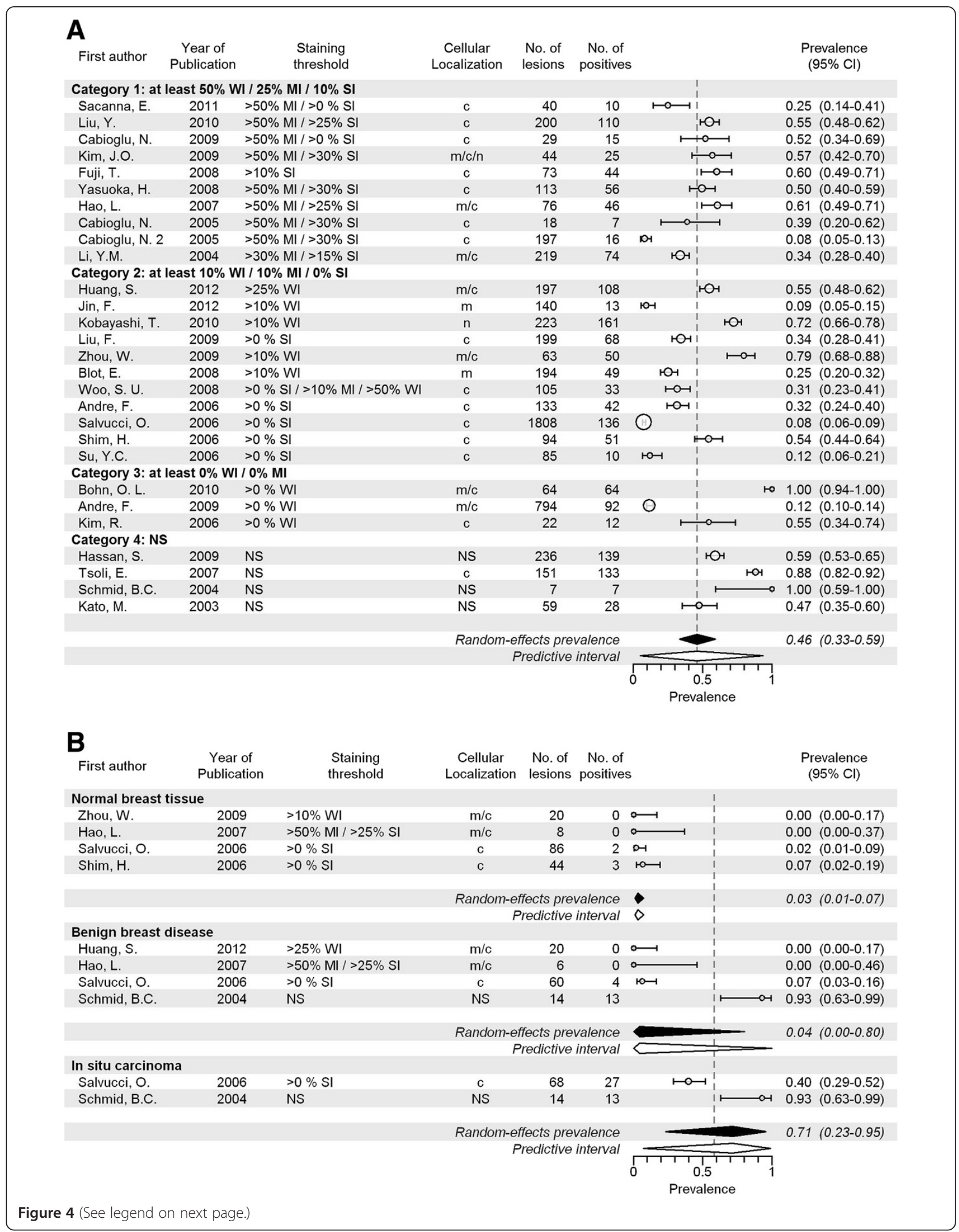


(See figure on previous page.)

Figure 4 Expression prevalence of CXCR4. A Systematic literature review of CXCR4 prevalence in breast cancer assessed by immunohistochemistry, according to reported staining threshold. Legend: Dashed gray reference line: overall random-effects prevalence estimate. Abbreviations: Staining threshold: weak intensity (WI), moderate intensity (MI), strong intensity (SI); Localization: cytoplasm (c), membrane (m); confidence interval (CI); not stated (NS). B Systematic literature review of CXCR4 prevalence in normal breast tissue, benign breast diseases and carcinoma in situ assessed by immunohistochemistry. Legend: Dashed line represents random effect summary prevalence estimate for invasive cancer within studies reporting also on normal, benign and/or precancerous breast tissue (6 studies). Abbreviations: Staining threshold: weak intensity (WI), moderate intensity (MI), strong intensity (SI); Localization: cytoplasm (c), membrane (m); confidence interval (CI); not stated (NS).

between-study variation was markedly lower when taking tumor size into account, and somewhat lower within subgroups of grade. In the studies investigating coexpression patterns of GLUT1 and CAIX, concordant presence or absence of CAIX and GLUT1 was found in 78/118 (66\%) [42], 45/59 (76\%) [45], and 45/48 (94\%) [69] of the cancers, respectively.

\section{CXCR4}

A total of 28 articles including 5,583 invasive cancers reported on CXCR4 expression, with a range of 7 to 1,808 cancers per study. The pooled prevalence of CXCR4 expression was 46\% (CI 33-59\%; Figure 4A and Table 2), with a range between studies of $8 \%$ to $100 \%$. For studies investigating membranous staining patterns only, the pooled prevalence was 16\% (CI 8-31\%; 2 studies; Additional file 17: Figure S3A) and when the studies providing best evidence for evaluation of molecular imaging targets were selected, this was 43\% (CI 25-63\%; 7 studies, Additional file 18: Figure S3B). CXCR4 prevalence increased with histological grade $(32 \%$ in grade II ( $\mathrm{p}=0.049)$ and $44 \%$ in grade III $(\mathrm{p}<0.001)$, compared to $26 \%$ in grade I; Additional file 19: Figure S3C), but no relation was found with tumor size (Additional file 20: Figure S3D). Furthermore, the prevalence of CXCR4 was higher in IDC than in ILC (46\% versus 35\%, p = 0.001; Additional file 21: Figure S3E). Expression prevalence was not related to slide construction method (Additional file 22: Figure S3F). In normal breast tissue, the pooled expression prevalence was 3\% (CI 1-7\%, p < $0.001 ; 4$ studies). Pooled prevalence in benign lesions was 4\% (CI 0-80\%, p < 0.001; 4 studies), and in carcinoma in situ 71\% (CI 23-95\%, $\mathrm{p}<0.001 ; 2$ studies) (Figure 4B). Between-study heterogeneity of studies investigating CXCR4 expression was large, both overall and within all subgroups (except for the two studies investigating membranous staining).

\section{IGF1R}

We analyzed a total of 31 articles including 8,463 invasive cancers (range of 8 to 2,871 cancers per study). The pooled prevalence of IGF1R expression was 46\% (CI 35-57\%; Figure $5 \mathrm{~A}$ and Table 2) with a range between studies of $10 \%$ to $99 \%$. For studies investigating membranous staining patterns only, the pooled prevalence was 38\% (CI 27-50\%; 15 studies, Additional file 23: Figure S4A) and when the studies providing best evidence for evaluation of molecular imaging targets were selected, this was 33\% (CI 22-46\%; 10 studies, Additional file 24: Figure S4B). In contrast to the other investigated markers, the pooled prevalence of IGF1R was lower in grade III versus grade I cancers (41\% versus 57\%, p < 0.001; Additional file 25: Figure S4C), and was lower in T3 cancers compared to T1 cancers (39\% versus 45\%, $\mathrm{p}=0.047$; Additional file 26: Figure S4D). Prevalence of IGF1R was higher in IDC compared to ILC ( $42 \%$ versus $25 \%, \mathrm{p}<0.001$; Additional file 27 : Figure S4E), and higher in studies using TMAs than in studies using full sections (57\% versus $34 \%, \mathrm{p}=0.032$; Additional file 28: Figure S4F). In normal breast tissue, the pooled expression prevalence was 74\% (CI 69-78\%, p = 0.109; 2 studies). Pooled prevalence in benign lesions was $73 \%$ (CI 66-79\%, $\mathrm{p}=0.137 ; 2$ studies), and in carcinoma in situ 33\% (CI 18-53\%, p = 0.869; 2 studies) (Figure 5B). Variation in results between studies was large, both overall and within the studies investigating membranous staining only and best evidence studies. Within groups of tumor grade and size, the between-study heterogeneity was very low, but the number of studies in these subgroups was small.

\section{Evaluation of publication bias}

The substantial overall between-study heterogeneity in prevalence estimates was confirmed by examination of the funnel plots (not shown). Furthermore, smaller studies (i.e. with lower precision) were more likely to report higher hypoxia marker prevalence rates (all Egger's tests $\mathrm{p}<0.05$, except for IGF1R). Funnel plots evaluating hypoxia marker prevalence rates according to tumor grade showed no evidence for publication bias for GLUT1 and CXCR4 (all Egger's tests $\mathrm{p}>0.25$ ), but indicated that smaller studies showed a larger increase in CAIX prevalence for grade III versus I and a larger decrease in IGF1R prevalence for grade II versus grade I tumors (i.e. more extreme effects in small studies; Egger's tests $\mathrm{p}=0.044$ and $\mathrm{p}=0.023$, respectively). We found no indication for publication bias when evaluating the studies reporting on hypoxia marker prevalence rates according to tumor size (all Egger's tests $\mathrm{p}>0.15$, or too few studies for evaluation). 


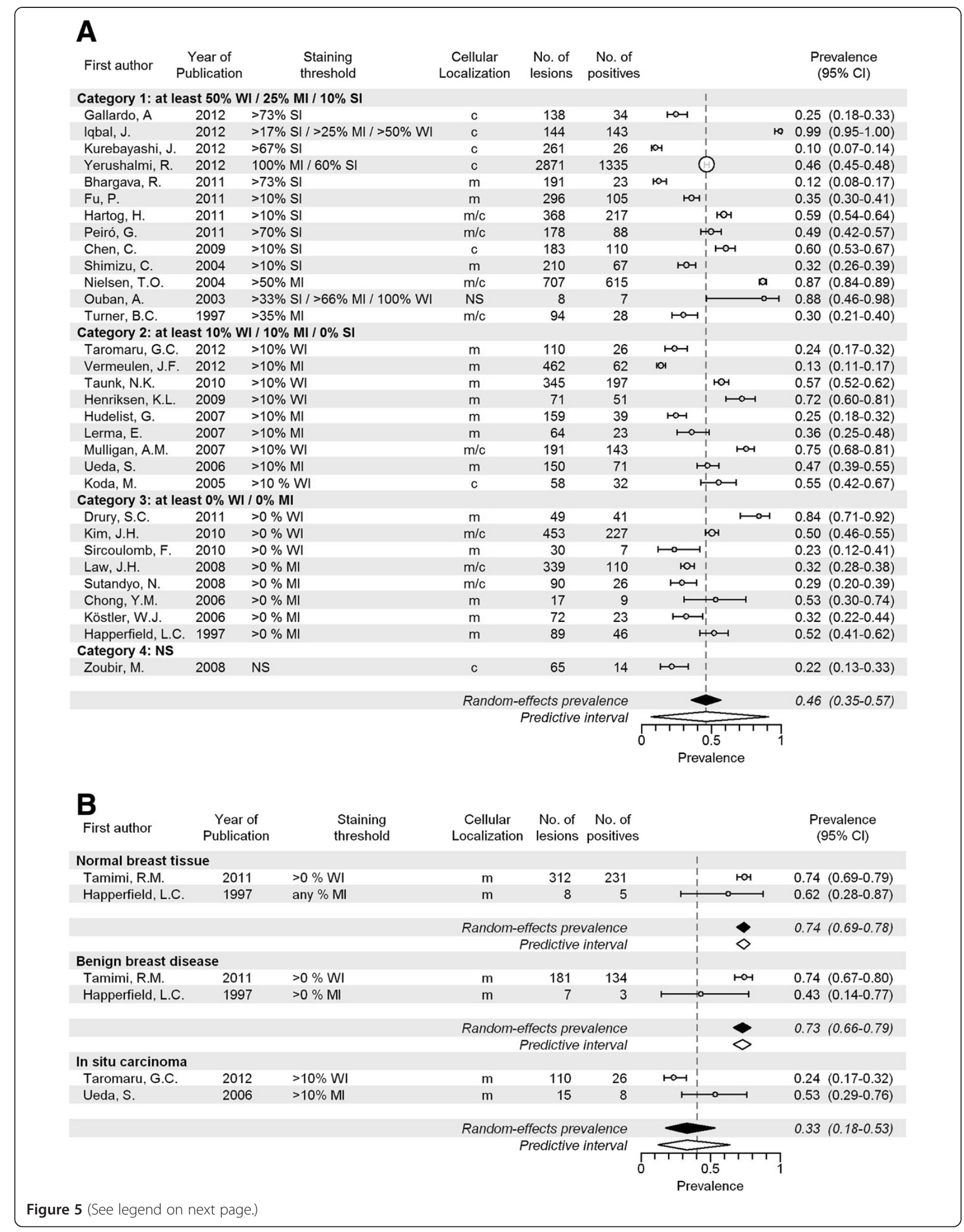


(See figure on previous page.)

Figure 5 Expression prevalence of IGF1R. A Systematic literature review of IGF1R prevalence in breast cancer assessed by immunohistochemistry, according to reported staining threshold. Legend: Dashed gray reference line: overall random-effects prevalence estimate. Abbreviations: Staining threshold: weak intensity (WI), moderate intensity (MI), strong intensity (SI); Localization: cytoplasm (c), membrane (m); confidence interval (Cl); not stated (NS). B Systematic literature review of IGF1R prevalence in normal breast tissue, benign breast diseases and carcinoma in situ assessed by immunohistochemistry. Legend: Dashed line represents random effect summary prevalence estimate for invasive cancer within studies reporting also on normal, benign and/or precancerous breast tissue ( 4 studies). Abbreviations: Staining threshold: weak intensity (WI), moderate intensity (MI), strong intensity (SI); Localization: cytoplasm (c), membrane (m); confidence interval (Cl); not stated (NS).

\section{Discussion}

In this comprehensive systematic literature review and meta-analysis, we reported on expression prevalence of the hypoxia-related proteins GLUT1, CAIX, CXCR4, and IGF1R in breast cancer and carcinoma in situ, benign breast disease and normal breast tissue. We included a total of 117 articles totaling 30,216 IHC results. Hypoxia marker prevalence rates were in the range of other potential targets for molecular imaging with antibodies or antibody fragments, e.g. Epidermal Growth Factor Receptor (EGFR) [157] or CD44v6 [158], and were higher than for example Human Epidermal Growth Factor Receptor 2 (HER2) [159]. Benign breast disease and non-affected breast tissue showed low expression, but the number of available studies was limited. The between-study variation of results was substantial and meta-regression showed several clinicopathological features of breast cancer to significantly influence hypoxia marker expression.

CAIX, GLUT1, and CXCR4 prevalence rates significantly increased with histological grade, which is consistent with the hypothesis that high grade tumors have a higher proliferation rate, causing neo-angiogenesis to lag behind tumor growth [160]. The resulting inadequate nutrient and oxygen supply causes activation of the hypoxia pathway $[161,162]$. Surprisingly, we found an inverse relation for IGF1R with histological grade. In analogy to histological grade, larger tumors may also express hypoxia markers more frequently, but we only found a significant positive relation for CAIX, and again an unexpected negative significant relation with IGF1R. We further found that hypoxia proteins are infrequently expressed in ILC, suggesting that hypoxia is not a common phenomenon in these cancers. Ercan et al. reported that only $3 \%$ of ILC expresses HIF $1 \alpha$, compared to $39 \%$ of IDC [163], suggesting that hypoxia is indeed rare in this subtype. We found significant lower expression prevalences in normal tissue and benign breast diseases compared to invasive breast cancer, showing high cancerspecificity of CAIX, GLUT1 and especially CXCR4. IGF1R was evaluated in few studies with non-significant results, so no conclusions can be drawn with respect to specificity of this target. Pooled expression prevalence rates of carcinoma in situ were at least comparable to (GLUT1 and IGF1R) or higher than (CAIX and CXCR4) invasive carcinoma, albeit based on few studies.
An increasing number of recent studies evaluated hypoxia marker expression using TMA. Although TMA allows for higher throughput than full section analyses, it may lead to underestimation of marker expression in presence of intra-tumoral heterogeneity. We found that CAIX and GLUT1 prevalence was significantly lower in TMA studies, presumably due to the sampling method used for TMA construction, in which necrotic regions that usually have the highest expression of hypoxiarelated proteins are avoided [65]. The lower prevalence of CAIX and GLUT1 in TMA studies could be interpreted as an indication of intratumoral heterogeneity of these markers. Although this interpretation is interesting, the applicability of TMAs for assessment of hypoxia marker expression needs to be reconsidered [164,165], even if their use has been justified for other markers (e.g. ER $\alpha$ and HER2 [143,166]).

With a view to molecular imaging, specificity of the imaging target is pivotal for every clinical application. The marked lower expression prevalence of CAIX, GLUT1 and CXCR4 in benign breast disease and normal breast tissue is thus highly promising. The specificity results for IGF1R are less encouraging, albeit based on only two studies. For early detection, a suitable target should be prevalent already in small tumors. Furthermore, evidence is mounting that current mammography screening may lead to substantial over-diagnosis [167] and picks-up tumors with favorable prognosis [168]. An imaging target that identifies small tumors with poor prognosis, e.g. grade III invasive breast cancers [169], would thus be especially valuable for screening. This combination makes GLUT1 an interesting candidate, with high expression in grade III cancers (58\%) and also highest expression in T1 tumors (although the latter not significantly different from T3 tumors). CXCR4 and CAIX also show higher expression in grade III cancers, but for CAIX expression prevalence is markedly lower in smaller lesions. For intra-operative guidance, a high prevalence in invasive cancer is not required, as tissue can be sampled for investigation of target expression pre-operatively. Such a target should ideally show low intratumoral heterogeneity to ascertain radical resection. Although this was not specifically addressed by individual studies, the difference in results between TMA and full-section studies may 
indicate that CAIX and GLUT1 have marked intratumoral heterogeneity and might therefore be less suitable for intra-operative application than CXCR4. Risk factors for incomplete tumor resection in current clinical practice include the presence of an extensive intraductal component [170], and the ILC histological subtype [171-175]. Especially CXCR4 shows high expression in DCIS, thus is potentially valuable for imaging of an extensive intraductal component. However, none of the markers show potential for ILC imaging.

None of the investigated markers showed a sufficient expression prevalence to allow sensitive molecular imaging with a single tracer only. For successful implementation (especially in a screening or diagnostic setting), a combination of tracers would be required to obtain a high sensitivity. However, all of the investigated markers here are expressed via the same (hypoxia-related) oncogenic pathway. The few studies that investigated co-expression patterns found that expression of these markers were indeed closely correlated. It would therefore be more advantageous to combine the hypoxia targets with targets from other oncogenic pathways, such as growth factors (e.g. EGFR or HER2), targets that are excreted in the tumor stroma (e.g. Vascular Endothelial Growth Factor (VEGF)), or less tumor-specific targets such as Mucin 1 (MUC1), Mammaglobin, or CD44v6 [36]. However, the aggregated nature of the obtained data did not allow us to investigate the best combination of targets or to investigate co-expression patterns.

To appreciate the results, one needs to acknowledge that studies employed various IHC protocols and assessment methodologies, as no standardized scoring system is established for these markers, in contrast to e.g. HER2 [176]. When we evaluated only studies that used relatively strict cut-offs (i.e. the studies providing best evidence for evaluation of molecular imaging targets) or studies investigating membranous staining only, the results were still comparable to the overall results. Nevertheless, as IHC may not reflect the functionality or availability of a marker in all situations, it remains unclear which or if any cut-off level relates to sufficient marker levels for molecular imaging in humans [177]. However, IHC remains the established standard for protein expression estimation since it allows for sensitive detection at the (sub-) cellular level, and is more reliable than assays measuring DNA or RNA levels because of post-translational processing.

\section{Conclusions}

We have shown that human expression prevalence and patterns of hypoxia-related markers support their potential as molecular imaging targets, with promising specificity. However, none of the evaluated markers shows sufficient prevalence in invasive cancer to be exploited as the sole target. Future research should focus on the identification of optimal combinations of candidate imaging targets, and dedicated studies are needed to assess the accuracy of such combinations to discriminate between breast cancer (subtypes) and benign breast lesions and normal tissue. The data from this review and such studies could help guide the choice of markers for breast cancer tracer development.

\section{Additional files}

\begin{abstract}
Additional file 1: Table S1A. Study characteristics of articles included in the review investigating CAIX expression prevalences in breast cancer carcinoma in situ, benign breast disease, and normal breast tissue Legend: a: mean; *: mean size in mm (range or SD); b: nuclear grade; ns: not stated; na: not applicable; o: tissue not investigated; $\bullet$ : tissue investigated; ๑: both TMA and full sections investigated; IDC: invasive ductal carcinoma; ILC: invasive lobular carcinoma; IBC: inflammatory breast cancer; $A B C$ : advanced breast cancer; TN: triple negative; LN: lymph node; TMA: tissue microarray; PT: phyllodes tumors; FA: fibroadenoma; M: distant metastasis; Obs.: number of observers evaluating staining result; +: positive; -: negative.
\end{abstract}

Additional file 2: Table S1B. Study characteristics of articles included in the review investigating GLUT1 expression prevalences in breast cancer, carcinoma in situ, benign breast disease, and normal breast tissue. Legend: a: mean; *: mean size in mm (range or SD); b: nuclear grade; ns: not stated; na: not applicable; o: tissue not investigated; $\bullet$ : tissue investigated; $\odot$ : both TMA and full sections investigated; IDC: invasive ductal carcinoma; ILC: invasive lobular carcinoma; IBC: inflammatory breast cancer; $\mathrm{ABC}$ : advanced breast cancer; TN: triple negative; LN: lymph node; TMA: tissue microarray; PT: phyllodes tumors; FA: fibroadenoma; M: distant metastasis; Obs.: number of observers evaluating staining result; +: positive; -: negative.

Additional file 3: Table S1C. Study characteristics of articles included in the review investigating CXCR4 expression prevalences in breast cancer, in situ carcinoma, benign breast disease, and normal breast tissue. Legend: a: mean; *: mean size in mm (range or SD); b: nuclear grade; ns: not stated; na: not applicable; o: tissue not investigated; tissue investigated; $\odot$ : both TMA and full sections investigated; IDC: invasive ductal carcinoma; ILC: invasive lobular carcinoma; IBC: inflammatory breast cancer; $A B C$ : advanced breast cancer; TN: triple negative; LN: lymph node; TMA: tissue microarray; PT: phyllodes tumors; FA: fibroadenoma; M: distant metastasis; Obs.: number of observers evaluating staining result; + : positive; -: negative.

Additional file 4: Table S1D. Study characteristics of articles included in the review investigating IGF1R expression prevalences in breast cancer, carcinoma in situ, benign breast disease, and normal breast tissue. Legend: a: mean; *: mean size in mm (range or SD); b: nuclear grade; ns: not stated; na: not applicable; o: tissue not investigated; $\bullet$ : tissue investigated; $\odot$ : both TMA and full sections investigated; IDC: invasive ductal carcinoma; ILC: invasive lobular carcinoma; IBC: inflammatory breast cancer; $A B C$ : advanced breast cancer; TN: triple negative; LN: lymph node; TMA: tissue microarray; PT: phyllodes tumors; FA: fibroadenoma; M: distant metastasis; Obs.: number of observers evaluating staining result; +: positive; -: negative.

Additional file 5: Figure S1A. CAIX - Membranous staining. Systematic literature review of CAIX prevalence in breast cancer assessed by immunohistochemistry for studies investigating membranous staining patterns only.

Additional file 6: Figure S1B. CAIX - Best evidence studies. Systematic literature review of CAIX prevalence in breast cancer assessed by immunohistochemistry for studies providing the best evidence for high expression levels.

Additional file 7: Figure S1C. CAIX - Histological grade. Systematic literature review of CAIX prevalence in breast cancer assessed by immunohistochemistry in relation to histological grade.

Additional file 8: Figure S1D. CAIX - Tumor size. Systematic literature review of CAIX prevalence in breast cancer assessed by immunohistochemistry in relation to tumor size. 
Additional file 9: Figure S1E. CAIX - Histology. Systematic literature review of CAIX prevalence in breast cancer assessed by immunohistochemistry in relation to histological subtype.

Additional file 10: Figure S1F. CAIX - Specimen handling. Systematic literature review of CAIX prevalence in breast cancer assessed by immunohistochemistry in relation to specimen handling method.

Additional file 11: Figure S2A. GLUT1 - Membranous staining. Systematic literature review of GLUT1 prevalence in breast cancer assessed by immunohistochemistry for studies investigating membranous staining patterns only.

Additional file 12: Figure S2B. GLUT1 - Best evidence studies. Systematic literature review of GLUT1 prevalence in breast cancer assessed by immunohistochemistry for studies providing the best evidence for high expression levels.

Additional file 13: Figure S2C. GLUT1 - Histological grade. Systematic literature review of GLUT1 prevalence in breast cancer assessed by immunohistochemistry in relation to histological grade.

Additional file 14: Figure S2D. GLUT1 - Tumor size. Systematic literature review of GLUT1 prevalence in breast cancer assessed by immunohistochemistry in relation to tumor size

Additional file 15: Figure S2E. GLUT1 - Histology. Systematic literature review of GLUT1 prevalence in breast cancer assessed by immunohistochemistry in relation to histological subtype.

Additional file 16: Figure S2F. GLUT1 - Specimen handling. Systematic literature review of GLUT1 prevalence in breast cancer assessed by immunohistochemistry in relation to specimen handling method.

Additional file 17: Figure S3A. CXCR4 - Membranous staining. Systematic literature review of CXCR4 prevalence in breast cancer assessed by immunohistochemistry for studies investigating membranous staining patterns only.

Additional file 18: Figure S3B. CXCR4 - Best evidence studies. Systematic literature review of CXCR4 prevalence in breast cancer assessed by immunohistochemistry for studies providing the best evidence for high expression levels.

Additional file 19: Figure S3C. CXCR4 - Histological grade. Systematic literature review of CXCR4 prevalence in breast cancer assessed by immunohistochemistry in relation to histological grade.

Additional file 20: Figure S3D. CXCR4 - Tumor size. Systematic literature review of CXCR4 prevalence in breast cancer assessed by immunohistochemistry in relation to tumor size.

Additional file 21: Figure S3E. CXCR4 - Histology. Systematic literature review of CXCR4 prevalence in breast cancer assessed by immunohistochemistry in relation to histological subtype.

Additional file 22: Figure S3F. CXCR4 - Specimen handling. Systematic literature review of CXCR4 prevalence in breast cancer assessed by immunohistochemistry in relation to specimen handling method.

Additional file 23: Figure S4A. IGF1R - Membranous staining Systematic literature review of IGF1R prevalence in breast cancer assessed by immunohistochemistry for studies investigating membranous staining patterns only.

Additional file 24: Figure S4B. IGF1R - Best evidence studies. Systematic literature review of IGF1R prevalence in breast cancer assessed by immunohistochemistry for studies providing the best evidence for high expression levels.

Additional file 25: Figure S4C. IGF1R - Histological grade. Systematic literature review of IGF1R prevalence in breast cancer assessed by immunohistochemistry in relation to histological grade.

Additional file 26: Figure S4D. IGF1R - Tumor size. Systematic literature review of IGFIR prevalence in breast cancer assessed by immunohistochemistry in relation to tumor size.

Additional file 27: Figure S4E. IGF1R - Histology. Systematic literature review of IGF1R prevalence in breast cancer assessed by immunohistochemistry in relation to histological subtype.
Additional file 28: Figure S4F. IGF1R - Specimen handling. Systematic literature review of IGF1R prevalence in breast cancer assessed by immunohistochemistry in relation to specimen handling method.

\section{Competing interests}

The authors declare that they have no competing interests.

\section{Authors' contributions}

$A A, A B, J V, W M, E v W, P v D$, and $S E$ conceived and designed the study. AA, $A \vee B$, and JV selected the articles. $A A, A v B, J V$, and SE analyzed the data. AA, $A \vee B$ and JV wrote the first draft of the manuscript. AA, AvB, JV, WM, EvW, PVD, and SE contributed to the writing of the manuscript, agree with the results and conclusions. All authors read and approved the final manuscript.

\section{Acknowledgements}

This work was supported by the MAMmary carcinoma MOlecular imaging for diagnostics and THerapeutics (MAMMOTH) project of the Dutch Center for Translational Molecular Medicine, by an unrestricted research grant of AEGON Inc. to PvD, and by the Dutch Cancer Society KWF by a research fellowship to SE.

\section{Author details}

'Department of Radiology, University Medical Center Utrecht, Utrecht, The Netherlands. ${ }^{2}$ Department of Pathology, University Medical Center Utrecht, Utrecht, The Netherlands. ${ }^{3}$ Division of Internal Medicine and Dermatology, University Medical Center Utrecht, Utrecht, The Netherlands. ${ }^{4}$ Julius Center of Health Sciences and Primary Care, University Medical Center Utrecht, Utrecht, The Netherlands.

Received: 11 April 2013 Accepted: 23 October 2013

Published: 10 November 2013

\section{References}

1. Sampath L, Wang W, Sevick-Muraca EM: Near infrared fluorescent optical imaging for nodal staging. J Biomed Opt 2008, 13(4):041312.

2. Goldenberg DM, Nabi HA: Breast cancer imaging with radiolabeled antibodies. Semin Nucl Med 1999, 29(1):41-48.

3. Mann RM, Hoogeveen YL, Blickman JG, Boetes C: MRI compared to conventional diagnostic work-up in the detection and evaluation of invasive lobular carcinoma of the breast: a review of existing literature. Breast Cancer Res Treat 2008, 107(1):1-14.

4. Leung JW: New modalities in breast imaging: digital mammography, positron emission tomography, and sestamibi scintimammography. Radiol Clin North Am 2002, 40(3):467-482.

5. Petralia G, Bonello L, Priolo F, Summers P, Bellomi M: Breast MR with special focus on DW-MRI and DCE-MRI. Cancer Imaging 2011, 11:76-90.

6. Frangioni JV: New technologies for human cancer imaging. J Clin Oncol 2008, 26(24):4012-4021.

7. Groheux D, Espie M, Giacchetti S, Hindie E: Performance of FDG PET/CT in the clinical management of breast cancer. Radiology 2013, 266(2):388-405.

8. Bos R, Zhong H, Hanrahan CF, Mommers EC, Semenza GL, Pinedo HM, Abeloff MD, Simons JW, van Diest PJ, van der Wall E: Levels of hypoxia-inducible factor-1 alpha during breast carcinogenesis. J Natl Cancer Inst 2001, 93(4):309-314.

9. Wykoff CC, Beasley N, Watson PH, Campo L, Chia SK, English R, Pastorek J, Sly WS, Ratcliffe P, Harris AL: Expression of the hypoxia-inducible and tumor-associated carbonic anhydrases in ductal carcinoma in situ of the breast. Am J Pathol 2001, 158(3):1011-1019.

10. Krohn KA, Link JM, Mason RP: Molecular imaging of hypoxia. J Nucl Cardiol 2008, 49(Suppl 2):129S-148S

11. Muda M, Gross AW, Dawson JP, He C, Kurosawa E, Schweickhardt R, Dugas M, Soloviev M, Bernhardt A, Fischer D, et al: Therapeutic assessment of SEED: a new engineered antibody platform designed to generate mono- and bispecific antibodies. Protein Eng Des Sel 2011, 24(5):447-454.

12. Hamers-Casterman C, Atarhouch T, Muyldermans S, Robinson G, Hamers C, Songa EB, Bendahman N, Hamers R: Naturally occurring antibodies devoid of light chains. Nature 1993, 363(6428):446-448.

13. Feldwisch J, Tolmachev V: Engineering of affibody molecules for therapy and diagnostics. Methods Mol Biol 2012, 899:103-126. 
14. Taroni P: Diffuse optical imaging and spectroscopy of the breast: a brief outline of history and perspectives. Photochem Photobiol Sci 2012, 11(2):241-250

15. Li XF, O'Donoghue JA: Hypoxia in microscopic tumors. Cancer Lett 2008, 264(2):172-180.

16. Bos R, van der Groep P, Greijer AE, Shvarts A, Meijer S, Pinedo HM Semenza GL, van Diest PJ, van der Wall E: Levels of hypoxia-inducible factor-1alpha independently predict prognosis in patients with lymph node negative breast carcinoma. Cancer 2003, 97(6):1573-1581.

17. Vaupel $P$, Thews $O$, Hoeckel M: Treatment resistance of solid tumors: role of hypoxia and anemia. Med Oncol 2001, 18(4):243-259.

18. Vaupel P, Mayer A, Briest S, Hockel M: Hypoxia in breast cancer: role of blood flow, oxygen diffusion distances, and anemia in the development of oxygen depletion. Adv Exp Med Biol 2005, 566:333-342.

19. Staller P, Sulitkova J, Lisztwan J, Moch H, Oakeley EJ, Krek W: Chemokine receptor CXCR4 downregulated by von Hippel-Lindau tumour suppressor pVHL. Nature 2003, 425(6955):307-311.

20. Cronin PA, Wang JH, Redmond HP: Hypoxia increases the metastatic ability of breast cancer cells via upregulation of CXCR4. BMC Cancer 2010, $10: 225$.

21. Peretz S, Kim C, Rockwell S, Baserga R, Glazer PM: IGF1 receptor expression protects against microenvironmental stress found in the solid tumor. Radiat Res 2002, 158(2):174-180.

22. Treins C, Giorgetti-Peraldi S, Murdaca J, Monthouel-Kartmann MN, Van Obberghen E: Regulation of hypoxia-inducible factor (HIF)-1 activity and expression of HIF hydroxylases in response to insulin-like growth factor I. Mol Endocrinol 2005, 19(5):1304-1317.

23. Riedemann J, Macaulay VM: IGF1R signalling and its inhibition. Endocr Relat Cancer 2006, 13(Suppl 1):S33-S43.

24. Hamza TH, van Houwelingen HC, Stijnen T: The binomial distribution of meta-analysis was preferred to model within-study variability. J Clin Epidemiol 2008, 61(1):41-51.

25. Higgins JP, Thompson SG, Spiegelhalter DJ: A re-evaluation of random-effects meta-analysis. J R Stat Soc Ser A Stat Soc 2009, 172(1):137-159.

26. Egger M, Davey Smith G, Schneider M, Minder C: Bias in meta-analysis detected by a simple, graphical test. BMJ 1997, 315(7109):629-634.

27. $R$ Core Team: $R$ : a language and environment for statistical computing, $R$ foundation for statistical computing. Vienna, Austria. 2012. http://www.R-project.org/.

28. Bates D, Maechler M, Bolker B: Ime4: Linear mixed-effects models using S4 classes. R package version 0.999999-0. 2012

http://CRAN.R-project.org/package=Ime4.

29. Schwarzer G: Meta: meta-analysis with R. R package version 2.1-1. 2012. http://CRAN.R-project.org/package=meta.

30. Ito S, Fukusato T, Nemoto T, Sekihara H, Seyama Y, Kubota S: Coexpression of glucose transporter 1 and matrix metalloproteinase- 2 in human cancers. J Natl Cancer Inst 2002, 94(14):1080-1091.

31. Younes $M$, Lechago LV, Somoano JR, Mosharaf M, Lechago J: Wide expression of the human erythrocyte glucose transporter Glut1 in human cancers. Cancer Res 1996, 56(5):1164-1167.

32. Betof AS, Rabbani ZN, Hardee ME, Kim SJ, Broadwater G, Bentley RC, Snyder SA, Vujaskovic Z, Oosterwijk E, Harris LN, et al: Carbonic anhydrase $\mathrm{IX}$ is a predictive marker of doxorubicin resistance in early-stage breast cancer independent of HER2 and TOP2A amplification. Br J Cancer 2012, 106(5):916-922.

33. Choi J, Jung WH, Koo JS: Metabolism-related proteins are differentially expressed according to the molecular subtype of invasive breast cancer defined by surrogate immunohistochemistry. Pathobiology 2013, 80(1):41-52.

34. Kornegoor $\mathrm{R}$, Verschuur-Maes AH, Buerger $\mathrm{H}$, Hogenes MC, de Bruin PC, Oudejans JJ, Hinrichs B, van Diest PJ: Fibrotic focus and hypoxia in male breast cancer. Mod Pathol 2012, 25(10):1397-1404

35. Tafreshi NK, Bui MM, Bishop K, Lloyd MC, Enkemann SA, Lopez AS, Abrahams D, Carter BW, Vagner J, Grobmyer SR, et al: Noninvasive detection of breast cancer lymph node metastasis using carbonic anhydrases IX and XII targeted imaging probes. Clin Cancer Res 2012, 18(1):207-219.

36. Vermeulen JF, van Brussel AS, van der Groep P, Morsink FH, Bult P, van der Wall $E$, van Diest PJ: Immunophenotyping invasive breast cancer: paving the road for molecular imaging. BMC Cancer 2012, 12(1):240
37. Beketic-Oreskovic L, Ozretic P, Rabbani ZN, Jackson IL, Sarcevic B, Levanat S, Maric P, Babic I, Vujaskovic Z: Prognostic significance of carbonic anhydrase IX (CA-IX), endoglin (CD105) and 8-hydroxy-2'-deoxyguanosine (8-OHdG) in breast cancer patients. Pathol Oncol Res 2011, 17(3):593-603.

38. Fox SB, Generali D, Berruti A, Brizzi MP, Campo L, Bonardi S, Bersiga A Allevi G, Milani M, Aguggini S, et al: The prolyl hydroxylase enzymes are positively associated with hypoxia-inducible factor-1alpha and vascular endothelial growth factor in human breast cancer and alter in response to primary systemic treatment with epirubicin and tamoxifen. Breast Cancer Res 2011, 13(1):R16.

39. Hyseni A, van der Groep P, van der Wall E, van Diest PJ: Subcellular FIH-1 expression patterns in invasive breast cancer in relation to HIF-1alpha expression. Cell Oncol 2011, 34(6):565-570.

40. Khurana A, Liu P, Mellone P, Lorenzon L, Vincenzi B, Datta K, Yang B, Linhardt RJ, Lingle W, Chien J, et al: HSulf-1 modulates FGF2- and hypoxia-mediated migration and invasion of breast cancer cells. Cancer Res 2011, 71(6):2152-2161

41. Lou Y, McDonald PC, Oloumi A, Chia S, Ostlund C, Ahmadi A, Kyle A, Auf Dem Keller A, Leung S, Huntsman D, et al: Targeting tumor hypoxia: suppression of breast tumor growth and metastasis by novel carbonic anhydrase IX inhibitors. Cancer Res 2011, 71(9):3364-3376.

42. Pinheiro C, Sousa B, Albergaria A, Paredes J, Dufloth R, Vieira D, Schmitt F, Baltazar F: GLUT1 and CAIX expression profiles in breast cancer correlate with adverse prognostic factors and MCT1 overexpression. Histol Histopathol 2011, 26(10):1279-1286.

43. Yan M, Jene $N$, Byrne D, Millar EK, O'Toole SA, McNeil CM, Bates GJ, Harris AL, Banham AH, Sutherland RL, et al: Recruitment of regulatory $T$ cells is correlated with hypoxia-induced CXCR4 expression, and is associated with poor prognosis in basal-like breast cancers. Breast Cancer Res 2011, 13(2):R47.

44. Zanetti JS, Soave DF, Oliveira-Costa JP, da Silveira GG, Ramalho LN, Garcia SB, Zucoloto S, Ribeiro-Silva A: The role of tumor hypoxia in MUC1-positive breast carcinomas. Virchows Arch 2011, 459(4):367-375.

45. Chen CL, Chu JS, Su WC, Huang SC, Lee WY: Hypoxia and metabolic phenotypes during breast carcinogenesis: expression of HIF-1alpha, GLUT1, and CAIX. Virchows Arch 2010, 457(1):53-61.

46. Dachs GU, Kano M, Volkova E, Morrin HR, Davey VC, Harris GC, Cheale M, Frampton C, Currie MJ, Wells JE, et al: A profile of prognostic and molecular factors in European and Maori breast cancer patients. BMC Cancer 2010, 10:543.

47. Jubb AM, Soilleux EJ, Turley H, Steers G, Parker A, Low I, Blades J, Li JL, Allen $P$, Leek $R$, et al: Expression of vascular notch ligand delta-like 4 and inflammatory markers in breast cancer. Am J Pathol 2010, 176(4):2019-2028.

48. Lancashire $L$, Powe DG, Reis-Filho JS, Rakha E, Lemetre C, Weigelt B, Abdel-Fatah TM, Green AR, Mukta R, Blamey R, et al: A validated gene expression profile for detecting clinical outcome in breast cancer using artificial neural networks. Breast Cancer Res Treat 2010, 120(1):83-93.

49. Koop EA, van Laar $T$, van Wichen DF, de Weger RA, Wall E, van Diest PJ: Expression of BNIP3 in invasive breast cancer: correlations with the hypoxic response and clinicopathological features. BMC Cancer 2009, 9:175.

50. Rakha EA, Elsheikh SE, Aleskandarany MA, Habashi HO, Green AR, Powe DG, El-Sayed ME, Benhasouna A, Brunet JS, Akslen LA, et al: Triple-negative breast cancer: distinguishing between basal and nonbasal subtypes. Clin Cancer Res 2009, 15(7):2302-2310.

51. Tan EY, Yan M, Campo L, Han C, Takano E, Turley H, Candiloro I, Pezzella F, Gatter KC, Millar EK, et al: The key hypoxia regulated gene CAIX is upregulated in basal-like breast tumours and is associated with resistance to chemotherapy. Br J Cancer 2009, 100(2):405-411.

52. Crabb SJ, Bajdik CD, Leung S, Speers CH, Kennecke H, Huntsman DG Gelmon KA: Can clinically relevant prognostic subsets of breast cancer patients with four or more involved axillary lymph nodes be identified through immunohistochemical biomarkers? A tissue microarray feasibility study. Breast Cancer Res 2008, 10(1):R6.

53. van der Groep P, Bouter A, Menko FH, van der Wall E, van Diest PJ: High frequency of HIF-1alpha overexpression in BRCA1 related breast cancer. Breast Cancer Res Treat 2008, 111(3):475-480. 
54. Kyndi M, Sorensen FB, Knudsen H, Alsner J, Overgaard M, Nielsen HM, Overgaard J: Carbonic anhydrase IX and response to postmastectomy radiotherapy in high-risk breast cancer: a subgroup analysis of the DBCG82 b and c trials. Breast Cancer Res 2008, 10(2):R24.

55. Garcia S, Dales JP, Charafe-Jauffret E, Carpentier-Meunier S, Andrac-Meyer L, Jacquemier J, Andonian C, Lavaut MN, Allasia C, Bonnier P, et al: Poor prognosis in breast carcinomas correlates with increased expression of targetable CD146 and c-Met and with proteomic basal-like phenotype. Hum Pathol 2007, 38(6):830-841.

56. Hussain SA, Ganesan R, Reynolds G, Gross L, Stevens A, Pastorek J, Murray PG, Perunovic B, Anwar MS, Billingham L, et al: Hypoxiaregulated carbonic anhydrase IX expression is associated with poor survival in patients with invasive breast cancer. Br J Cancer 2007, 96(1):104-109.

57. Tan EY, Campo L, Han C, Turley H, Pezzella F, Gatter KC, Harris AL, Fox SB: Cytoplasmic location of factor-inhibiting hypoxia-inducible factor is associated with an enhanced hypoxic response and a shorter survival in invasive breast cancer. Breast Cancer Res 2007, 9(6):R89.

58. Trastour C, Benizri E, Ettore F, Ramaioli A, Chamorey E, Pouyssegur J, Berra E: HIF-1alpha and CA IX staining in invasive breast carcinomas: prognosis and treatment outcome. Int J Cancer 2007, 120(7):1451-1458.

59. Brennan DJ, Jirstrom K, Kronblad A, Millikan RC, Landberg G, Duffy MJ, Ryden L, Gallagher WM, O'Brien SL: CA IX is an independent prognostic marker in premenopausal breast cancer patients with one to three positive lymph nodes and a putative marker of radiation resistance. Clin Cancer Res 2006, 12(21):6421-6431.

60. Generali D, Fox SB, Berruti A, Brizzi MP, Campo L, Bonardi S, Wigfield SM, Bruzzi P, Bersiga A, Allevi G, et al: Role of carbonic anhydrase IX expression in prediction of the efficacy and outcome of primary epirubicin/tamoxifen therapy for breast cancer. Endocr Relat Cancer 2006, 13(3):921-930

61. Generali D, Berruti A, Brizzi MP, Campo L, Bonardi S, Wigfield S, Bersiga A, Allevi G, Milani M, Aguggini S, et al: Hypoxia-inducible factor-1alpha expression predicts a poor response to primary chemoendocrine therapy and disease-free survival in primary human breast cancer. Clin Cancer Res 2006, 12(15):4562-4568.

62. Vleugel MM, Shvarts D, van der Wall E, van Diest PJ: p300 and p53 levels determine activation of HIF-1 downstream targets in invasive breast cancer. Hum Pathol 2006, 37(8):1085-1092.

63. Van den Eynden GG, Van der Auwera I, Van Laere SJ, Colpaert CG, Turley H, Harris AL, van Dam P, Dirix LY, Vermeulen PB, Van Marck EA: Angiogenesis and hypoxia in lymph node metastases is predicted by the angiogenesis and hypoxia in the primary tumour in patients with breast cancer. Br J Cancer 2005, 93(10):1128-1136.

64. Kuijper A, van der Groep P, van der Wall E, van Diest PJ: Expression of hypoxia-inducible factor 1 alpha and its downstream targets in fibroepithelial tumors of the breast. Breast Cancer Res 2005, 7(5):R808-R818.

65. Vleugel MM, Greijer AE, Shvarts A, van der Groep P, van Berkel M, Aarbodem $Y$, van Tinteren $H$, Harris AL, van Diest PJ, van der Wall E: Differential prognostic impact of hypoxia induced and diffuse HIF-1alpha expression in invasive breast cancer. J Clin Pathol 2005, 58(2):172-177.

66. Blackwell KL, Dewhirst MW, Liotcheva V, Snyder S, Broadwater G, Bentley R, Lal A, Riggins G, Anderson S, Vredenburgh J, et al: HER-2 gene amplification correlates with higher levels of angiogenesis and lower levels of hypoxia in primary breast tumors. Clin Cancer Res 2004 10(12 Pt 1):4083-4088

67. Cooper C, Liu GY, Niu YL, Santos S, Murphy LC, Watson PH: Intermittent hypoxia induces proteasome-dependent down-regulation of estrogen receptor alpha in human breast carcinoma. Clin Cancer Res 2004, 10(24):8720-8727.

68. Colpaert CG, Vermeulen PB, Benoy I, Soubry A, van Roy F, van Beest P, Goovaerts G, Dirix LY, van Dam P, Fox SB, et al: Inflammatory breast cancer shows angiogenesis with high endothelial proliferation rate and strong E-cadherin expression. Br J Cancer 2003, 88(5):718-725.

69. Tomes L, Emberley E, Niu Y, Troup S, Pastorek J, Strange K, Harris A, Watson $\mathrm{PH}$ : Necrosis and hypoxia in invasive breast carcinoma. Breast Cancer Res Treat 2003, 81(1):61-69.

70. Bartosova M, Parkkila S, Pohlodek K, Karttunen TJ, Galbavy S, Mucha V, Harris AL, Pastorek J, Pastorekova S: Expression of carbonic anhydrase IX in breast is associated with malignant tissues and is related to overexpression of c-erbB2. J Patho/ 2002, 197(3):314-321.

71. Chia SK, Wykoff CC, Watson PH, Han C, Leek RD, Pastorek J, Gatter KC, Ratcliffe $\mathrm{P}$, Harris AL: Prognostic significance of a novel hypoxia-regulated marker, carbonic anhydrase IX, in invasive breast carcinoma. J Clin Oncol 2001, 19(16):3660-3668.

72. Jang SM, Han H, Jang KS, Jun YJ, Jang SH, Min KW, Chung MS, Paik SS: The glycolytic Phenotype is correlated with aggressiveness and poor prognosis in invasive ductal carcinomas. J Breast Cancer 2012, 15(2):172-180.

73. Carvalho KC, Cunha IW, Rocha RM, Ayala FR, Cajaiba MM, Begnami MD, Vilela RS, Paiva GR, Andrade RG, Soares FA: GLUT1 expression in malignant tumors and its use as an immunodiagnostic marker. Clinics 2011, 66 (6):965-972.

74. Hussein YR, Bandyopadhyay S, Semaan A, Ahmed Q, Albashiti B, Jazaerly T, Nahleh Z, Ali-Fehmi R: Glut-1 expression correlates with basal-like breast cancer. Trans/ Oncol 2011, 4(6):321-327.

75. Airley R, Evans A, Mobasheri A, Hewitt SM: Glucose transporter Glut-1 is detectable in peri-necrotic regions in many human tumor types but not normal tissues: Study using tissue microarrays. Ann Anat 2010 192(3):133-138.

76. Koda M, Kanczuga-Koda L, Sulkowska M, Surmacz E, Sulkowski S: Relationships between hypoxia markers and the leptin system, estrogen receptors in human primary and metastatic breast cancer: effects of preoperative chemotherapy. BMC Cancer 2010, 10:320.

77. Koo JS, Jung W: Alteration of REDD1-mediated mammalian target of rapamycin pathway and hypoxia-inducible factor-1alpha regulation in human breast cancer. Pathobiology 2010, 77(6):289-300.

78. Schmidt M, Voelker HU, Kapp M, Krockenberger M, Dietl J, Kammerer U: Glycolytic phenotype in breast cancer: activation of Akt, up-regulation of GLUT1, TKTL1 and down-regulation of M2PK. J Cancer Res Clin Oncol 2010, 136(2):219-225.

79. Godoy A, Ulloa V, Rodriguez F, Reinicke K, Yanez AJ, Garcia Mde L, Medina RA, Carrasco M, Barberis S, Castro T, et al: Differential subcellular distribution of glucose transporters GLUT1-6 and GLUT9 in human cancer: ultrastructural localization of GLUT1 and GLUT5 in breast tumor tissues. J Cell Physiol 2006, 207(3):614-627.

80. Kuo SJ, Wu YC, Chen CP, Tseng HS, Chen DR: Expression of glucose transporter-1 in Taiwanese patients with breast carcinoma-a preliminary report. Kaohsiung J Med Sci 2006, 22(7):339-345.

81. Stackhouse BL, Williams H, Berry P, Russell G, Thompson P, Winter JL, Kute T: Measurement of glut-1 expression using tissue microarrays to determine a race specific prognostic marker for breast cancer. Breast Cancer Res Treat 2005, 93(3):247-253.

82. Laudanski P, Koda M, Kozlowski L, Swiatecka J, Wojtukiewicz M, Sulkowski S, Wolczynski S: Expression of glucose transporter GLUT-1 and estrogen receptors ER-alpha and ER-beta in human breast cancer. Neoplasma 2004 51(3):164-168.

83. Ravazoula P, Batistatou A, Aletra C, Ladopoulos J, Kourounis G, Tzigounis B: Immunohistochemical expression of glucose transporter Glut1 and cyclin D1 in breast carcinomas with negative lymph nodes. Eur J Gynaecol Oncol 2003, 24(6):544-546.

84. Bos R, van der Hoeven JJ, van der Wall E, van der Groep P, van Diest PJ, Comans EF, Joshi U, Semenza GL, Hoekstra OS, Lammertsma AA, et al: Biologic correlates of (18)fluorodeoxyglucose uptake in human breast cancer measured by positron emission tomography. J Clin Oncol 2002, 20(2):379-387.

85. Brown RS, Goodman TM, Zasadny KR, Greenson JK, Wahl RL: Expression of hexokinase II and Glut-1 in untreated human breast cancer. Nucl Med Bio 2002, 29(4):443-453.

86. Kang SS, Chun YK, Hur MH, Lee HK, Kim YJ, Hong SR, Lee JH, Lee SG, Park YK: Clinical significance of glucose transporter 1 (GLUT1) expression in human breast carcinoma. Jpn J Cancer Res 2002, 93(10):1123-1128.

87. Alo PL, Visca P, Botti C, Galati GM, Sebastiani V, Andreano T, Di Tondo U, Pizer ES: Immunohistochemical expression of human erythrocyte glucose transporter and fatty acid synthase in infiltrating breast carcinomas and adjacent typical/atypical hyperplastic or normal breast tissue. Am J Clin Pathol 2001, 116(1):129-134.

88. Avril N, Menzel M, Dose J, Schelling M, Weber W, Janicke F, Nathrath W, Schwaiger M: Glucose metabolism of breast cancer assessed by 18 F-FDG PET: histologic and immunohistochemical tissue analysis. J Nucl Med 2001, 42(1):9-16. 
89. Binder C, Binder L, Marx D, Schauer A, Hiddemann W: Deregulated simultaneous expression of multiple glucose transporter isoforms in malignant cells and tissues. Anticancer Res 1997, 17(6D):4299-4304

90. Younes M, Brown RW, Mody DR, Fernandez L, Laucirica R: GLUT1 expression in human breast carcinoma: correlation with known prognostic markers. Anticancer Res 1995, 15(6B):2895-2898.

91. Brown RS, Wahl RL: Overexpression of Glut-1 glucose transporter in human breast cancer. an immunohistochemical study. Cancer 1993, 72(10):2979-2985.

92. Huang S, Ouyang N, Lin L, Chen L, Wu W, Su F, Yao Y, Yao H: HGF-induced PKCzeta activation increases functional CXCR4 expression in human breast cancer cells. PLoS One 2012, 7(1):e29124.

93. Jin F, Brockmeier U, Otterbach F, Metzen E: New insight into the SDF-1/ CXCR4 axis in a breast carcinoma model: hypoxia-induced endothelia SDF-1 and tumor cell CXCR4 are required for tumor cell intravasation. Mol Cancer Res 2012, 10(8):1021-1031

94. Ibrahim T, Sacanna E, Gaudio M, Mercatali L, Scarpi E, Zoli W, Serra P, Ricci R, Serra L, Kang Y, et al: Role of RANK, RANKL, OPG, and CXCR4 tissue markers in predicting bone metastases in breast cancer patients. Clin Breast Cancer 2011, 11(6):369-375

95. Sacanna E, Ibrahim T, Gaudio M, Mercatali L, Scarpi E, Zoli W, Serra P, Bravaccini $S$, Ricci R, Serra L, et al: The role of CXCR4 in the prediction of bone metastases from breast cancer: a pilot study. Oncology 2011, 80(3-4):225-231.

96. Bohn OL, Nasir I, Brufsky A, Tseng GC, Bhargava R, MacManus K, Chivukula M: Biomarker profile in breast carcinomas presenting with bone metastasis. Int J Clin Exp Pathol 2009, 3(2):139-146.

97. Kobayashi T, Tsuda H, Moriya T, Yamasaki T, Kikuchi R, Ueda S, Omata J, Yamamoto J, Matsubara O: Expression pattern of stromal cell-derived factor-1 chemokine in invasive breast cancer is correlated with estrogen receptor status and patient prognosis. Breast Cancer Res Treat 2010, 123(3):733-745.

98. Liu Y, Ji R, Li J, Gu Q, Zhao X, Sun T, Wang J, Du Q, Sun B: Correlation effect of EGFR and CXCR4 and CCR7 chemokine receptors in predicting breast cancer metastasis and prognosis. J Exp Clin Cancer Res 2010, 29:16

99. Andre F, Xia W, Conforti R, Wei Y, Boulet T, Tomasic G, Spielmann M, Zoubir $M$, Berrada N, Arriagada R, et al: CXCR4 expression in early breast cancer and risk of distant recurrence. Oncologist 2009, 14(12):1182-1188.

100. Cabioglu N, Sahin AA, Morandi P, Meric-Bernstam F, Islam R, Lin HY, Bucana CD, Gonzalez-Angulo AM, Hortobagyi GN, Cristofanilli M: Chemokine receptors in advanced breast cancer: differential expression in metastatic disease sites with diagnostic and therapeutic implications. Ann Oncol 2009, 20(6):1013-1019.

101. Hassan S, Ferrario C, Saragovi U, Quenneville L, Gaboury L, Baccarelli A Salvucci O, Basik M: The influence of tumor-host interactions in the stromal cell-derived factor-1/CXCR4 ligand/receptor axis in determining metastatic risk in breast cancer. Am J Pathol 2009, 175(1):66-73.

102. Kim J-O, Suh K-S, Lee D-H, Sul H-J, Lee J-U, Song K-S: Expression of CXCR4 and SDF-1a in Primary Breast Cancers and Metastatic Lymph Nodes. $J$ Breast Cancer 2009, 12(4):249-256.

103. Liu F, Lang R, Wei J, Fan Y, Cui L, Gu F, Guo X, Pringle GA, Zhang X, Fu L: Increased expression of SDF-1/CXCR4 is associated with lymph node metastasis of invasive micropapillary carcinoma of the breast. Histopathology 2009, 54(6):741-750.

104. Yasuoka H, Kodama R, Tsujimoto M, Yoshidome K, Akamatsu H, Nakahara M, Inagaki M, Sanke T, Nakamura Y: Neuropilin-2 expression in breast cancer: correlation with lymph node metastasis, poor prognosis, and regulation of CXCR4 expression. BMC Cancer 2009, 9:220.

105. Zhou W, Jiang Z, Liu N, Xu F, Wen P, Liu Y, Zhong W, Song X, Chang X, Zhang $X$, et al: Down-regulation of CXCL12 mRNA expression by promoter hypermethylation and its association with metastatic progression in human breast carcinomas. J Cancer Res Clin Oncol 2009, 135(1):91-102.

106. Blot E, Laberge-Le Couteulx S, Jamali H, Cornic M, Guillemet C, Duval C, Hellot MF, Pille JY, Picquenot JM, Veyret C: CXCR4 membrane expression in node-negative breast cancer. Breast J 2008, 14(3):268-274.

107. Fujii T, Kawahara A, Basaki Y, Hattori S, Nakashima K, Nakano K, Shirouzu K, Kohno K, Yanagawa T, Yamana $H$, et al: Expression of HER2 and estrogen receptor alpha depends upon nuclear localization of Y-box binding protein-1 in human breast cancers. Cancer Res 2008, 68(5):1504-1512.
108. Woo SU, Bae JW, Kim CH, Lee JB, Koo BW: A significant correlation between nuclear CXCR4 expression and axillary lymph node metastasis in hormonal receptor negative breast cancer. Ann Surg Oncol 2008, 15(1):281-285

109. Yasuoka H, Tsujimoto M, Yoshidome K, Nakahara M, Kodama R, Sanke T, Nakamura Y: Cytoplasmic CXCR4 expression in breast cancer: induction by nitric oxide and correlation with lymph node metastasis and poor prognosis. BMC Cancer 2008, 8:340.

110. Hao L, Zhang C, Qiu Y, Wang L, Luo Y, Jin M, Zhang Y, Guo TB, Matsushima K: Recombination of CXCR4, VEGF, and MMP-9 predicting lymph node metastasis in human breast cancer. Cancer Lett 2007, 253(1):34-42.

111. Tsoli E, Tsantoulis PK, Papalambros A, Perunovic B, England D, Rawlands DA, Reynolds GM, Vlachodimitropoulos D, Morgan SL, Spiliopoulou CA, et al: Simultaneous evaluation of maspin and CXCR4 in patients with breast cancer. J Clin Pathol 2007, 60(3):261-266.

112. Andre F, Cabioglu N, Assi H, Sabourin JC, Delaloge S, Sahin A, Broglio K, Spano JP, Combadiere C, Bucana C, et al: Expression of chemokine receptors predicts the site of metastatic relapse in patients with axillary node positive primary breast cancer. Ann Oncol 2006, 17(6):945-951.

113. Kim R, Arihiro K, Emi M, Tanabe K, Osaki A: Potential role of HER-2; in primary breast tumor with bone metastasis. Oncol Rep 2006, 15(6):1477-1484.

114. Salvucci O, Bouchard A, Baccarelli A, Deschenes J, Sauter G, Simon R, Bianchi $R$, Basik M: The role of CXCR4 receptor expression in breast cancer: a large tissue microarray study. Breast Cancer Res Treat 2006, 97(3):275-283

115. Shim H, Lau SK, Devi S, Yoon Y, Cho HT, Liang Z: Lower expression of CXCR4 in lymph node metastases than in primary breast cancers: potential regulation by ligand-dependent degradation and HIF-1alpha. Biochem Biophys Res Commun 2006, 346(1):252-258.

116. Su YC, Wu MT, Huang CJ, Hou MF, Yang SF, Chai CY: Expression of CXCR4 is associated with axillary lymph node status in patients with early breast cancer. Breast 2006, 15(4):533-539.

117. Cabioglu N, Sahin A, Doucet M, Yavuz E, Igci A, OY E, Aktas E, Bilgic S, Kiran B, Deniz G, et al: Chemokine receptor CXCR4 expression in breast cancer as a potential predictive marker of isolated tumor cells in bone marrow. Clin Exp Metastasis 2005, 22(1):39-46.

118. Cabioglu N, Yazici MS, Arun B, Broglio KR, Hortobagyi GN, Price JE, Sahin A CCR7 and CXCR4 as novel biomarkers predicting axillary lymph node metastasis in T1 breast cancer. Clin Cancer Res 2005, 11(16):5686-5693.

119. Li YM, Pan Y, Wei Y, Cheng X, Zhou BP, Tan M, Zhou X, Xia W, Hortobagyi GN, Yu D, et al: Upregulation of CXCR4 is essential for HER2-mediated tumor metastasis. Cancer Cell 2004, 6(5):459-469.

120. Schmid BC, Rudas M, Rezniczek GA, Leodolter S, Zeillinger R: CXCR4 is expressed in ductal carcinoma in situ of the breast and in atypical ductal hyperplasia. Breast Cancer Res Treat 2004, 84(3):247-250.

121. Kato M, Kitayama J, Kazama S, Nagawa H: Expression pattern of CXC chemokine receptor-4 is correlated with lymph node metastasis in human invasive ductal carcinoma. Breast Cancer Res 2003, 5(5):R144-R150.

122. Gallardo A, Lerma E, Escuin D, Tibau A, Munoz J, Ojeda B, Barnadas A, Adrover $E$, Sanchez-Tejada L, Giner D, et al: Increased signalling of EGFR and IGF1R, and deregulation of PTEN/PI3K/Akt pathway are related with trastuzumab resistance in HER2 breast carcinomas. Br J Cancer 2012, 106(8):1367-1373

123. Fu $P$, Ibusuki M, Yamamoto $Y$, Yamamoto S, Fujiwara S, Murakami K, Zheng S, Iwase $\mathrm{H}$ : Quantitative determination of insulin-like growth factor 1 receptor mRNA in formalin-fixed paraffin-embedded tissues of invasive breast cancer. Breast Cancer 2012, 19(4):321-328.

124. Iqbal J, Thike AA, Cheok PY, Tse GM, Tan PH: Insulin growth factor receptor-1 expression and loss of PTEN protein predict early recurrence in triple-negative breast cancer. Histopathology 2012 61(4):652-659.

125. Kurebayashi J, Kanomata N, Shimo T, Yamashita T, Aogi K, Nishimura R, Shimizu C, Tsuda H, Moriya T, Sonoo H: Marked lymphovascular invasion, progesterone receptor negativity, and high Ki67 labeling index predict poor outcome in breast cancer patients treated with endocrine therapy alone. Breast Cancer 2012. Epub ahead of print.

126. Taromaru GC, DE Olivera VM, Silva MA, Montor WR, Bagnoli F, Rinaldi JF, Aoki T: Interaction between cyclooxygenase-2 and insulin-like growth factor in breast cancer: a new field for prevention and treatment. Oncol Lett 2012, 3(3):682-688. 
127. Yerushalmi R, Gelmon KA, Leung S, Gao D, Cheang M, Pollak M, Turashvili G, Gilks BC, Kennecke H: Insulin-like growth factor receptor (IGF-1R) in breast cancer subtypes. Breast Cancer Res Treat 2012, 132(1):131-142.

128. Bhargava R, Beriwal S, McManus K, Dabbs DJ: Insulin-like growth factor receptor-1 (IGF-1R) expression in normal breast, proliferative breast lesions, and breast carcinoma. Appl Immunohistochem Mol Morphol 2011, 19(3):218-225

129. Drury SC, Detre S, Leary A, Salter J, Reis-Filho J, Barbashina V, Marchio C, Lopez-Knowles E, Ghazoui Z, Habben K, et al: Changes in breast cancer biomarkers in the IGF1R/PI3K pathway in recurrent breast cancer after tamoxifen treatment. Endocr Relat Cancer 2011, 18(5):565-577.

130. Fu P, Ibusuki M, Yamamoto Y, Hayashi M, Murakami K, Zheng S, Iwase H: Insulin-like growth factor-1 receptor gene expression is associated with survival in breast cancer: a comprehensive analysis of gene copy number, mRNA and protein expression. Breast Cancer Res Treat 2011 130(1):307-317.

131. Hartog H, Horlings HM, van der Vegt B, Kreike B, Ajouaou A, van de Vijver MJ, Marike Boezen $H$, de Bock GH, van der Graaf WT, Wesseling J: Divergent effects of insulin-like growth factor-1 receptor expression on prognosis of estrogen receptor positive versus triple negative invasive ductal breast carcinoma. Breast Cancer Res Treat 2011, 129(3):725-736.

132. Peiro G, Adrover E, Sanchez-Tejada L, Lerma E, Planelles M, Sanchez-Paya J, Aranda Fl, Giner D, Gutierrez-Avino FJ: Increased insulin-like growth factor-1 receptor mRNA expression predicts poor survival in immunophenotypes of early breast carcinoma. Mod Pathol 2011, 24(2):201-208.

133. Tamimi RM, Colditz GA, Wang Y, Collins LC, Hu R, Rosner B, Irie HY, Connolly JL, Schnitt SJ: Expression of IGF1R in normal breast tissue and subsequent risk of breast cancer. Breast Cancer Res Treat 2011, 128(1):243-250.

134. Kim JH, Cho YH, Park YL, Sohn JH, Kim HS: Prognostic significance of insulin growth factor-I receptor and insulin growth factor binding protein-3 expression in primary breast cancer. Oncol Rep 2010, 23(4):989-995

135. Sircoulomb F, Bekhouche I, Finetti P, Adelaide J, Ben Hamida A, Bonansea J, Raynaud S, Innocenti C, Charafe-Jauffret E, Tarpin C, et al: Genome profiling of ERBB2-amplified breast cancers. BMC Cancer 2010, 10:539.

136. Taunk NK, Goyal S, Moran MS, Yang Q, Parikh R, Haffty BG: Prognostic significance of IGF-1R expression in patients treated with breast-conserving surgery and radiation therapy. Radiother Oncol 2010, 96(2):204-208

137. Chen C, Zhou Z, Sheehan CE, Slodkowska E, Sheehan CB, Boguniewicz A Ross JS: Overexpression of WWP1 is associated with the estrogen receptor and insulin-like growth factor receptor 1 in breast carcinoma. Int J Cancer 2009, 124(12):2829-2836.

138. Henriksen $\mathrm{KL}$, Rasmussen $\mathrm{BB}$, Lykkesfeldt AE, Moller S, Ejlertsen $B$ Mouridsen HT: An ER activity profile including ER, PR, BCl-2 and IGF-IR may have potential as selection criterion for letrozole or tamoxifen treatment of patients with advanced breast cancer. Acta Oncol 2009, 48(4):522-531.

139. Peiro G, Benlloch S, Sanchez-Tejada L, Adrover E, Lerma E, Peiro FM, Sanchez-Paya J, Aranda Fl: Low activation of Insulin-like Growth Factor 1Receptor (IGF1R) is associated with local recurrence in early breast carcinoma. Breast Cancer Res Treat 2009, 117(2):433-441.

140. Law JH, Habibi G, Hu K, Masoudi H, Wang MY, Stratford AL, Park E, Gee JM, Finlay $\mathrm{P}$, Jones $\mathrm{HE}$, et al: Phosphorylated insulin-like growth factor-i/insulin receptor is present in all breast cancer subtypes and is related to poor survival. Cancer Res 2008, 68(24):10238-10246.

141. Sutandyo N, Suzanna E, Haryono SJ, Reksodiputro AH: Signaling pathways in early onset sporadic breast cancer of patients in Indonesia. Acta Med Indones 2008, 40(3):139-145.

142. Zoubir M, Mathieu MC, Mazouni C, Liedtke C, Corley L, Geha S, Bouaziz J, Spielmann M, Drusche F, Symmans WF, et al: Modulation of ER phosphorylation on serine 118 by endocrine therapy: a new surrogate marker for efficacy. Ann Oncol 2008, 19(8):1402-1406.

143. Henriksen KL, Rasmussen BB, Lykkesfeldt AE, Moller S, Ejlertsen B, Mouridsen HT: Semi-quantitative scoring of potentially predictive markers for endocrine treatment of breast cancer: a comparison between whole sections and tissue microarrays. J Clin Pathol 2007 60(4):397-404

144. Hudelist G, Wagner T, Rosner M, Fink-Retter A, Gschwantler-Kaulich D, Czerwenka K, Kroiss R, Tea M, Pischinger K, Kostler WJ, et al: Intratumoral IGF-I protein expression is selectively upregulated in breast cancer patients with BRCA1/2 mutations. Endocr Relat Cancer 2007, 14(4):1053-1062.

145. Lerma E, Peiro G, Ramon T, Fernandez S, Martinez D, Pons C, Munoz F, Sabate JM, Alonso C, Ojeda B, et al: Immunohistochemical heterogeneity of breast carcinomas negative for estrogen receptors, progesterone receptors and Her2/neu (basal-like breast carcinomas). Mod Pathol 2007 20(11):1200-1207.

146. Mulligan AM, O'Malley FP, Ennis M, Fantus IG, Goodwin PJ: Insulin receptor is an independent predictor of a favorable outcome in early stage breast cancer. Breast Cancer Res Treat 2007, 106(1):39-47.

147. Chong YM, Williams SL, Elkak A, Sharma AK, Mokbel K: Insulin-like growth factor 1 (IGF-1) and its receptor mRNA levels in breast cancer and adjacent non-neoplastic tissue. Anticancer Res 2006, 26(1A):167-173.

148. Kostler WJ, Hudelist G, Rabitsch W, Czerwenka K, Muller R, Singer CF, Zielinski CC: Insulin-like growth factor-1 receptor (IGF-1R) expression does not predict for resistance to trastuzumab-based treatment in patients with Her-2/neu overexpressing metastatic breast cancer. J Cancer Res Clin Oncol 2006, 132(1):9-18.

149. Ueda S, Tsuda H, Sato K, Takeuchi H, Shigekawa T, Matsubara O, Hiraide H, Mochizuki H: Alternative tyrosine phosphorylation of signaling kinases according to hormone receptor status in breast cancer overexpressing the insulin-like growth factor receptor type 1. Cancer Sci 2006, 97(7):597-604

150. Koda M, Przystupa W, Jarzabek K, Wincewicz A, Kanczuga-Koda L, Tomaszewski J, Sulkowska M, Wolczynski S, Sulkowski S: Expression of insulin-like growth factor-I receptor, estrogen receptor alpha, $\mathrm{Bcl}-2$ and Bax proteins in human breast cancer. Oncol Rep 2005, 14(1):93-98.

151. Nielsen TO, Andrews HN, Cheang M, Kucab JE, Hsu FD, Ragaz J, Gilks CB, Makretsov N, Bajdik CD, Brookes C, et al: Expression of the insulin-like growth factor I receptor and urokinase plasminogen activator in breast cancer is associated with poor survival: potential for intervention with 17-allylamino geldanamycin. Cancer Res 2004, 64(1):286-291.

152. Shimizu C, Hasegawa T, Tani Y, Takahashi F, Takeuchi M, Watanabe T, Ando M, Katsumata N, Fujiwara Y: Expression of insulin-like growth factor 1 receptor in primary breast cancer: immunohistochemical analysis. Hum Pathol 2004, 35(12):1537-1542.

153. Koda M, Sulkowski S, Garofalo C, Kanczuga-Koda L, Sulkowska M, Surmacz E: Expression of the insulin-like growth factor-I receptor in primary breast cancer and lymph node metastases: correlations with estrogen receptors alpha and beta. Horm Metab Res 2003, 35(11-12):794-801.

154. Ouban A, Muraca P, Yeatman T, Coppola D: Expression and distribution of insulin-like growth factor-1 receptor in human carcinomas. Hum Pathol 2003, 34(8):803-808.

155. Happerfield LC, Miles DW, Barnes DM, Thomsen LL, Smith P, Hanby A: The localization of the insulin-like growth factor receptor 1 (IGFR-1) in benign and malignant breast tissue. J Pathol 1997, 183(4):412-417.

156. Turner BC, Haffty BG, Narayanan L, Yuan J, Havre PA, Gumbs AA, Kaplan L, Burgaud $J$, Carter D, Baserga $R$, et al: Insulin-like growth factor-I receptor overexpression mediates cellular radioresistance and local breast cancer recurrence after lumpectomy and radiation. Cancer Res 1997, 57(15):3079-3083.

157. Klijn JG, Berns PM, Schmitz PI, Foekens JA: The clinical significance of epidermal growth factor receptor (EGF-R) in human breast cancer: a review on 5232 patients. Endocr Rev 1992, 13(1):3-17.

158. Heider KH, Kuthan H, Stehle G, Munzert G: CD44v6: a target for antibody-based cancer therapy. Cancer Immunol Immunother 2004 53(7):567-579.

159. Menard S, Balsari A, Casalini P, Tagliabue E, Campiglio M, Bufalino R, Cascinelli N: HER-2-positive breast carcinomas as a particular subset with peculiar clinical behaviors. Clin Cancer Res 2002, 8(2):520-525.

160. Urruticoechea A, Smith IE, Dowsett M: Proliferation marker Ki-67 in early breast cancer. J Clin Oncol 2005, 23(28):7212-7220.

161. Brahimi-Horn MC, Chiche J, Pouyssegur J: Hypoxia and cancer. J Mol Med 2007, 85(12):1301-1307.

162. Semenza GL: Targeting HIF-1 for cancer therapy. Nature reviews Cancer 2003, 3(10):721-732

163. Ercan C, Vermeulen JF, Hoefnagel $L$, Bult $P$, van der Groep $P$, van der Wall $E$, van Diest PJ: HIF-1alpha and NOTCH signaling in ductal and lobular carcinomas of the breast. Cell Oncol 2012, 35(6):435-442.

164. van Diest PJ, Vleugel MM, van der Wall E: Expression of HIF-1alpha in human tumours. J Clin Pathol 2005, 58(3):335-336. 
165. Van Diest PJ, Vleugel MM, Van Der Groep P, Van Der Wall E: VEGF-D and HIF-1alpha in breast cancer. J Clin Pathol 2005, 58(3):335. author reply 336.

166. Zhang D, Salto-Tellez M, Putti TC, Do E, Koay ES: Reliability of tissue microarrays in detecting protein expression and gene amplification in breast cancer. Mod Pathol 2003, 16(1):79-84.

167. Bleyer A, Welch HG: Effect of three decades of screening mammography on breast-cancer incidence. N Engl J Med 2012, 367(21):1998-2005.

168. Mook S, Veer $\sqcup$ V't, Rutgers EJ, Ravdin PM, Van De Velde AO, Van Leeuwen FE, Visser O, Schmidt MK: Independent prognostic value of screen detection in invasive breast cancer. J Natl Cancer Inst 2011, 103(7):585-597.

169. Rakha EA, Reis-Filho JS, Baehner F, Dabbs DJ, Decker T, Eusebi V, Fox SB, Ichihara S, Jacquemier J, Lakhani SR, et al: Breast cancer prognostic classification in the molecular era: the role of histological grade. Breast Cancer Res 2010, 12(4):207.

170. Luini A, Rososchansky J, Gatti G, Zurrida S, Caldarella P, Viale G, Rosali Dos Santos G, Frasson A: The surgical margin status after breast-conserving surgery: discussion of an open issue. Breast Cancer Res Treat 2009, 113(2):397-402.

171. Sakr RA, Poulet B, Kaufman GJ, Nos C, Clough KB: Clear margins for invasive lobular carcinoma: a surgical challenge. Eur J Surg Oncol 2011, 37(4):350-356

172. Dillon MF, Hill AD, Fleming FJ, O'Doherty A, Quinn CM, McDermott EW, O'Higgins N: Identifying patients at risk of compromised margins following breast conservation for lobular carcinoma. Am J Surg 2006, 191(2):201-205.

173. Takehara M, Tamura M, Kameda H, Ogita M: Examination of breast conserving therapy in lobular carcinoma. Breast Cancer 2004, 11(1):69-72.

174. Moore MM, Borossa G, Imbrie JZ, Fechner RE, Harvey JA, Slingluff CL Jr, Adams RB, Hanks JB: Association of infiltrating lobular carcinoma with positive surgical margins after breast-conservation therapy. Ann Surg 2000, 231(6):877-882.

175. Hussien M, Lioe TF, Finnegan J, Spence RA: Surgical treatment for invasive lobular carcinoma of the breast. Breast 2003, 12(1):23-35.

176. Jacobs TW, Gown AM, Yaziji H, Barnes MJ, Schnitt SJ: Specificity of HercepTest in determining HER-2/neu status of breast cancers using the United States Food and Drug Administration-approved scoring system. J Clin Oncol 1999, 17(7):1983-1987.

177. Amos KD, Adamo B, Anders CK: Triple-negative breast cancer: an update on neoadjuvant clinical trials. Int J Breast cancer 2012, 2012:385978.

doi:10.1186/1471-2407-13-538

Cite this article as: Adams et al.: The potential of hypoxia markers as target for breast molecular imaging - a systematic review and metaanalysis of human marker expression. BMC Cancer 2013 13:538.

\section{Submit your next manuscript to BioMed Central and take full advantage of:}

- Convenient online submission

- Thorough peer review

- No space constraints or color figure charges

- Immediate publication on acceptance

- Inclusion in PubMed, CAS, Scopus and Google Scholar

- Research which is freely available for redistribution

Submit your manuscript at www.biomedcentral.com/submit
Ciomed Central 